\title{
Concise Large-Scale Synthesis of Tomatidine, A Potent Antibiotic Natural Product
}

\author{
Chad Normandin and Pierre-Luc Boudreault *
}

Institut de Pharmacologie, Université of Sherbrooke, Sherbrooke, QC J1H 5N4, Canada

* Correspondence: Pierre-Luc.Boudreault@USherbrooke.ca

\begin{abstract}
Tomatidine has recently generated a lot of interest amongst the pharmacology, medicine, and biology fields of study, especially for its newfound activity as an antibiotic agent capable of targeting multiple strains of bacteria. In the light of its low natural abundance and high cost, an efficient and scalable multi-gram synthesis of tomatidine has been developed. This synthesis uses a Suzuki-Miyaura-type coupling reaction as a key step to graft an enantiopure F-ring side chain to the steroidal scaffold of the natural product, which was accessible from low-cost and commercially available diosgenin. A Lewis acid-mediated spiroketal opening followed by an azide substitution and reduction sequence is employed to generate the spiroaminoketal motif of the natural product. Overall, this synthesis produced $5.2 \mathrm{~g}$ in a single pass in 15 total steps and $15.2 \%$ yield using a methodology that is atom economical, scalable, and requires no flash chromatography purifications.
\end{abstract}

Keywords: tomatidine; antibiotics; alkaloids; steroids; Staphylococcus aureus; small-colony variants; large-scale

check for

updates

Citation: Normandin, C.;

Boudreault, P.-L. Concise Large-Scale Synthesis of Tomatidine, A Potent Antibiotic Natural Product. Molecules 2021, 26, 6008. https://doi.org/ $10.3390 /$ molecules 26196008

Academic Editor: David Barker

Received: 12 September 2021 Accepted: 30 September 2021 Published: 3 October 2021

Publisher's Note: MDPI stays neutral with regard to jurisdictional claims in published maps and institutional affiliations.

Copyright: (c) 2021 by the authors. Licensee MDPI, Basel, Switzerland. This article is an open access article distributed under the terms and conditions of the Creative Commons Attribution (CC BY) license (https:// creativecommons.org/licenses/by/ $4.0 /)$.

\section{Introduction}

The genus Solanum consists of over 2000 species of plants widely distributed over the world, from which over 600 natural products have been isolated [1]. Ten percent of these products are alkaloid steroids, which are classified into the Veratrum and Solanum alkaloid families [2]. Tomatidine (TO, 1), which belongs to the solanidine subfamily of Solanum, has recently gathered great interest from the scientific community for its biological and medicinal applications stemming from its anabolic [3], antioxidant [4], neuroprotective [5], antiviral [6,7], anticancer [8], and most importantly, antibiotic [9-13] properties. Our research group originally discovered the antibiotic potential of $\mathbf{1}$ against Staphylococcus aureus and its virulent small-colony variants (SCV), which are responsible for resistance and persistence of the pathogen $[9,10]$. Structure-activity relationship (SAR) studies based on modifications of the natural product showed that it was possible to bring the minimum inhibitory concentration (MIC) of $S$. aureus from $>128 \mu \mathrm{g} / \mathrm{mL}$ to $2 \mu \mathrm{g} / \mathrm{mL}$ using the most active derivative FC04-100 [11,12]. Furthermore, the MIC could be brought down from $64 \mu \mathrm{g} / \mathrm{mL}$ to $8 \mu \mathrm{g} / \mathrm{mL}$ for the SCVs (8-fold potency increase) when TO was used synergistically with the aminoglycoside antibiotic gentamycin [12].

Accessibility is a challenge commonly encountered in the study of biologically active natural products [14]. Recently, our group has shown that the potent alkaloid tomatidine could be synthesized on gram-scale [15], with only one other methodology producing a close derivative (tomatidenol, ${ }^{\Delta 5-6}$-1) [16] in small quantities (50 mg) through non-strategic redox [17]. With SAR studies still on-going in our laboratory and considering the common profound scientific interest, high costs (> USD 1500/g) and scarce natural availability of this steroid, we tackled the ambitious challenge of developing a new synthesis capable of decagram scale quantities of $\mathbf{1}$.

Despite providing over $2 \mathrm{~g}$ of tomatidine, we identified multiple shortcomings in our previous synthetic methodology that would render a scale-up largely inefficient. Our previous methodology (Scheme 1a, red) [15] relied on a chiral auxiliary to set the stereocenter of 
iodo-3, followed by its introduction to 5 as a temperature-sensitive organolithium reagent to obtain adduct 4 , which then underwent acid-mediated spiroketalization to obtain 2 . To develop a scalable and atom-economical synthesis, inefficient steps of the first-generation synthesis, such as the use of the heavy TBDPS protecting group, requirement of a chiral auxiliary, and the arduous temperature control of the organolithium 3 generation on higher scales, had to be addressed. To further optimize the overall practicality of this methodology, we also set the ambitious objective of avoiding the use of flash chromatography purifications for the whole sequence, aiming to develop clean transformations and to obtain pure intermediates from recrystallizations, distillations, and silica pads only.

\section{(a) Retrosynthetic analysis of 1}

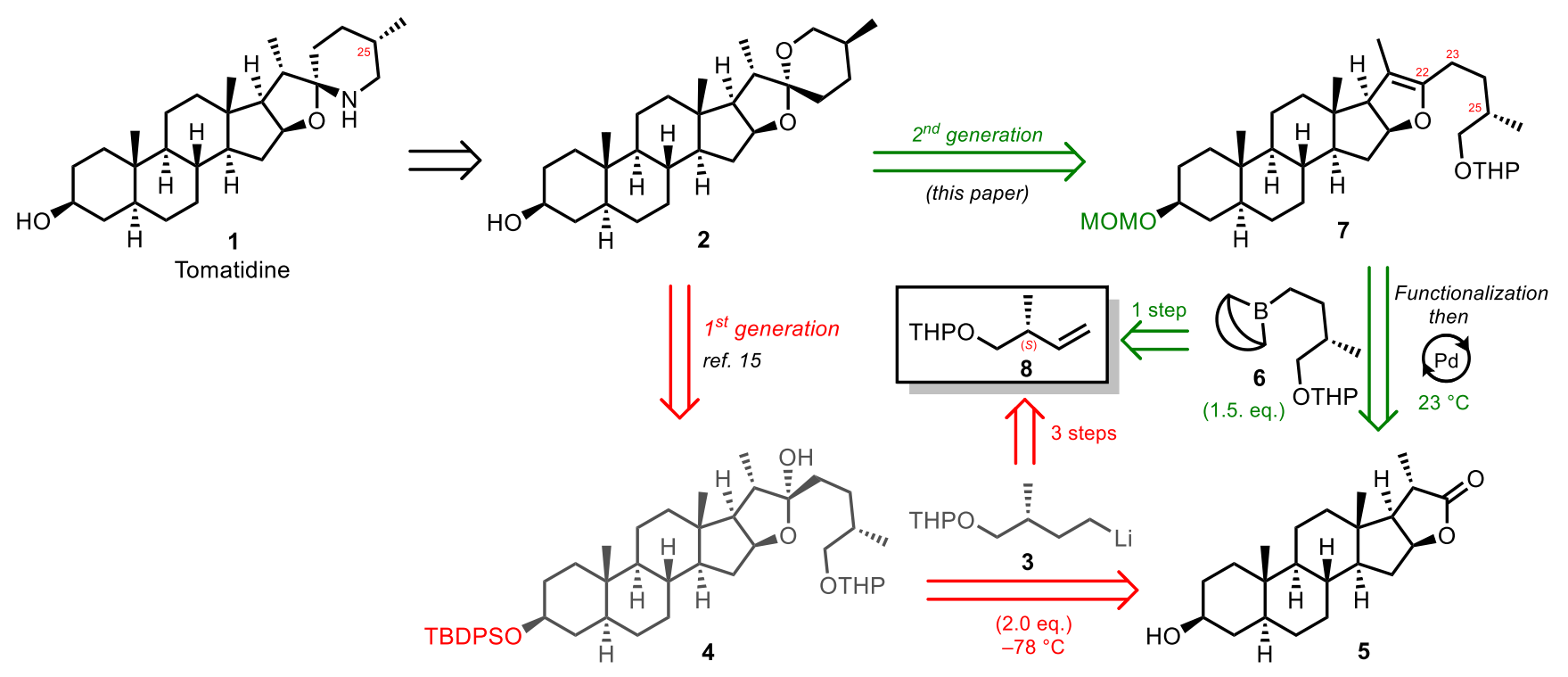

(b) Suzuki-Miyaura crosscoupling between an iodoglycal and an alkylborane generated in situ (Tan et al.)<smiles>[R6]C[C@H]1OC=C[C@@H](O)[C@H]1[R9]</smiles><smiles></smiles>

$R=T I P S$

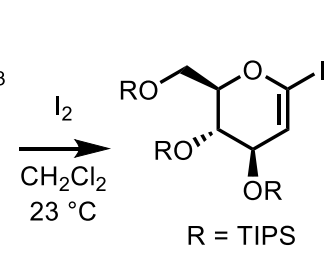

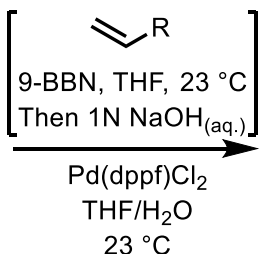

$23{ }^{\circ} \mathrm{C}$<smiles>[R]CCC1=C[C@@H]([R6])[C@@H]([R9])[C@H](C[R])O1</smiles>

Scheme 1. (a) Retrosynthetic analysis of Tomatidine and (b) proposed coupling methodology.

We recognized early in our new retrosynthetic analysis (Scheme 1a, green) that the $\mathrm{C}_{22}-\mathrm{C}_{23}$ bond was an efficient disconnection strategy for introducing a side chain synthon containing the required $(S)-C_{25}$ of the natural product. We opted to use the SuzukiMiyaura reaction to combine the steroid scaffold 5 to the required asymmetric synthon 8 (as organoborane 6). This reaction is known to be a generally efficient and cost-effective method to give access to pharmaceutical intermediates and natural products even on industrial scales [18]. The union of an iodo enol ether (as iodo dihydropyran) to an alkylborane generated in situ from a parent olefin through Pd catalysis has been previously demonstrated by Tan et al. [19] to afford the desired adducts in high yields (Scheme $1, b)$. We planned to use and optimize this methodology by circumventing the use of the stannyl intermediate in the preparation of the required iodo enol ether. Succeeding at this critical step would, following cyclisation, lead us to spirostanol 2 , which would lead us to tomatidine 1 through our previously developed sequence of five reactions [15].

Preparing the required enol ether following this strategy would start from functionalization of lactone 5, followed by coupling to alkylborane 6 to obtain adduct 7, which, after 
an acid-catalyzed spiroketalization, would deliver 2 . This approach requires less of the valuable asymmetric synthon 8 ( 1.5 eq., vs. 2.0 eq. required in the first-generation synthesis) and avoids the temperature dependency of its union to the steroid backbone. Scaffold 5 could be obtained in two steps on large scale from diosgenin [20], an inexpensive (USD $0.30 / \mathrm{g}$ ) sapogenin, obtained mainly from the acidic hydrolysis of wild yam (Dioscorea) on industrial scale [21].

\section{Results and Discussion}

Our efforts started with the preparation of the first anchor for the Pd-mediated SuzukiMiyaura reaction, the steroid core. We initially probed the reactivity of lactone 5 as its $\mathrm{C}_{3}$-protected congeners $\mathbf{9 a - c}$ (Scheme 2) in the hope of obtaining enol triflates 10a-c, which would give access to the required coupling partner following our retrosynthetic strategy. Conversion of ketones and lactones to their corresponding enol triflates followed by crosscoupling is a strategic way to access diverse complex natural products in a convergent manner [22]. Despite extensive efforts, lactones $9 \mathbf{a}-\mathbf{c}$ resisted triflation under common conditions (LiHMDS/KHMDS/LDA then $\mathrm{Ph}_{2} \mathrm{NTf} / \mathrm{Tf}_{2} \mathrm{O} /$ Comin's reagent) [22,23], most likely because of the strong steric hindrance imparted by the $C_{18}$ and $C_{21}$ methyl groups restricting the deprotonation at $\mathrm{C}_{20}$. This hypothesis was rationalized when attempts at quenching the supposed enolates with deuterated protic sources $\left(\mathrm{D}_{2} \mathrm{O}, \mathrm{AcOD}\right)$ yielded no ${ }^{2} \mathrm{H}$ incorporation at $\mathrm{C}_{20}$.
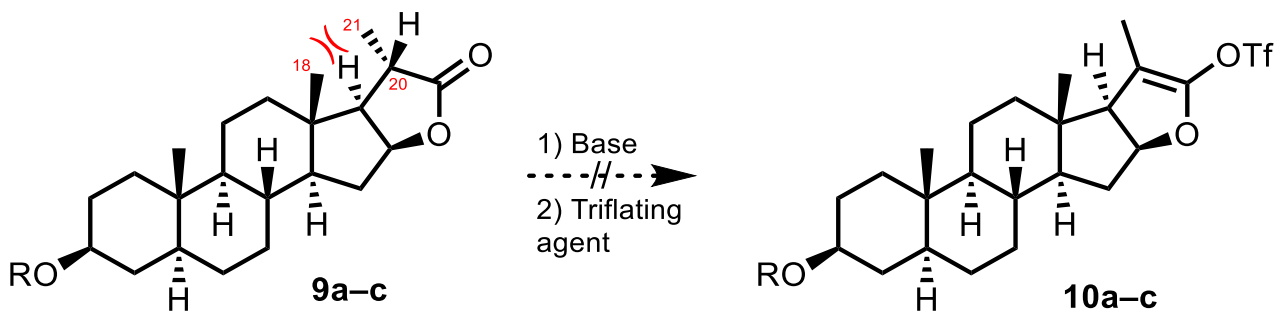

$\mathrm{R}=(\mathrm{a}) \mathrm{MOM}(\mathrm{b}) \mathrm{THP}(\mathrm{c}) \mathrm{TBS}$

Scheme 2. Failed attempts at obtaining triflates 10a-c.

Following this roadblock, we investigated the work of Boeckman et al., which probed the reactivity of cyclic enol ethers (as 3,4-dihydropyrans) by deprotonation using strong bases, followed by treatment with a wide range of electrophiles [24,25]. To the same extent, we aimed to prepare the equivalent enol ether (as 2,3-dihydrofuran) derivative of 5 to create the required reactive handle for the Suzuki-Miyaura reaction following these conditions. Heavy silyl protecting groups (TBS, TBDPS) were not considered to protect the $\mathrm{C}_{3}$ alcohol since studies have previously shown unpredictable migratory behavior in the required strongly basic conditions [26,27] and were not ideal in terms of mass economy. In contrast, the MOM-protecting group was chosen owing to its ability to withstand strong basic media, low molecular weight, and acid lability, enabling its removal during the acid-promoted spiroketalization whilst saving a deprotection step and enhancing the overall efficiency.

We began our synthesis (Scheme 3) by treating 5 with $\mathrm{MOMCl}$ in the presence of DIPEA/TBAI [28] to afford MOM-protected lactone 9a, followed by reduction with ${ }^{i} \mathrm{Bu}_{2} \mathrm{AlH}$ [20] to produce the corresponding hemiacetal 11 in $95 \%$ yield in two steps on $2 \mathrm{~g}$ scale as an inconsequential mix of diastereoisomers (2:1). Despite the screening of different catalytic acidic conditions previously used in dehydrations of hemiacetals [29], 12 could not be obtained cleanly without removing the MOM-protecting group. Fortunately, the activation of the hemiacetal using $\mathrm{MsCl}$ and subsequent elimination with an excess of $\mathrm{Et}_{3} \mathrm{~N}$ at high temperatures [30] afforded the desired enol ether 12 in a modest $65 \%$ yield on a $2 \mathrm{~g}$ scale after passage through a short silica pad. 


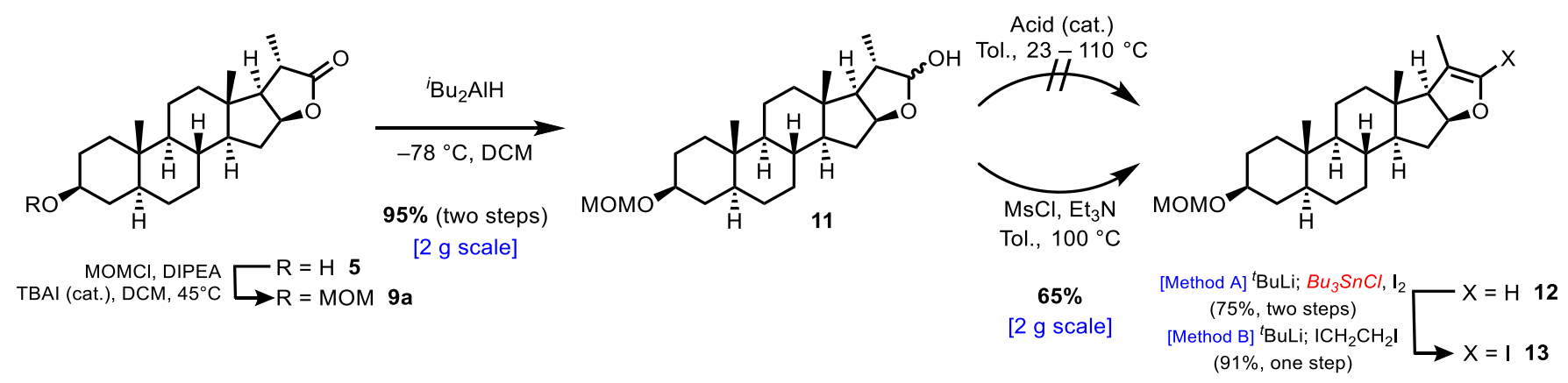

Scheme 3. Preparation of iodo enol ether 13.

Next, we subjected 12 to similar conditions as those described by Boeckman [24,25]. Following lithiation, attempts at reacting various electrophilic halogen sources such as NBS, DBDMH, NCS, NIS, and $\mathrm{I}_{2}$ failed to produce the expected halogenated derivative. However, treatment of the organolithium intermediate with $\mathrm{Bu}_{3} \mathrm{SnCl}$ cleanly yielded the stannyl enol ether, which afforded the iodo enol ether $\mathbf{1 3}$ after reaction with molecular iodine (Scheme 3, Method A) [31]. Other interesting protocols have been reported for the synthesis of the equivalent obtained stannyl enol ether starting from a lactone derivative; however, they were too inefficient to be conducted on a large-scale [32,33]. Although the reaction with $\mathrm{Bu}_{3} \mathrm{SnCl}$ provided a direct route to 13 , the use of a tin intermediate is chemically inefficient, dangerous to handle on such scales, and traces of the toxic heavy metal would likely be carried to the final product used in in vivo and SAR studies. We circumvented this liability by reacting lithio-12 with 1,2-diiodoethane (1,2-DIE) (Scheme 3, Method B), a niche electrophilic source of iodine. [34] To our delight, this methodology cleanly afforded $\mathbf{1 3}$ in $91 \%$ yield on a $2 \mathrm{~g}$ scale. A slight optimization of this protocol allowed us to use 3.0 eq. of both reagents ( ${ }^{t} \mathrm{BuLi}$ and 1,2-DIE) instead of the original 4.0 eq. prescribed, while maintaining $>97 \%$ conversion on gram scale. Further lowering of the equivalents ( $<3.0$ eq.) led to poor conversions $(<75 \%)$.

With the anchor of the Pd-mediated cross coupling installed on the steroidal scaffold, we then devised a scalable route to the desired olefin 8 . Commercially available $(R)$ Roche ester 14 was protected as THP followed by reduction using $\mathrm{LiAlH}_{4}$ to yield (S)monoprotected diol 15 in $81 \%$ yield on a $25 \mathrm{~g}$ scale after distillation (Scheme 4) [35]. Subsequent oxidation using the Cornforth reagent (PDC) in conjunction with silica gel [36] cleanly yielded the corresponding aldehyde, which was then immediately subjected to a Wittig olefination [37]. The desired olefin 8 was cleanly obtained following a short silica pad in $62 \%$ yield after two steps on a $30 \mathrm{~g}$ scale.<smiles>COC(=O)[C@H](C)CO</smiles>

14
1) 3,4-DHP PPTS $(5 \% \mathrm{~mol})$

2) $\mathrm{LiAlH}_{4}, \mathrm{Et}_{2} \mathrm{O}$ 0 to $23^{\circ} \mathrm{C}$

$\mathbf{8 1 \%}$ (two steps)

[25 g scale]

[Distillation]

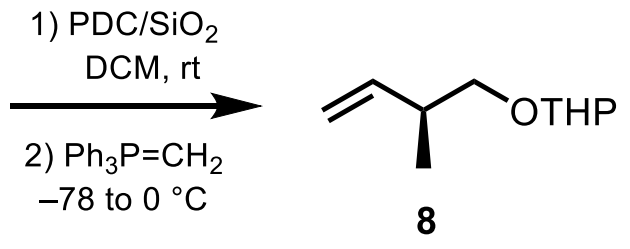

$\mathbf{6 2 \%}$ (two steps)

[30 g scale]

[Silica pad]

Scheme 4. Scalable access to synthon 8 .

Having obtained both coupling partners, we then explored the scalability of the reported one-pot transformation to obtain adduct 7 from 6 and 13. Fortunately, we did not encounter any problems during the scale-up testing (up to $8 \mathrm{~g}$ ) using the reported conditions [19]. Attempts at optimization by lowering the equivalents of alkylborane 6 
(from 1.5 through to 1.1 eq.) and catalyst loading (20 mol\% through to $1 \mathrm{~mol} \%$ ) were met with high amounts of reduction back to parent enol ether 12 (up to 20\%), so the originally reported conditions were employed. The transformation sequence from 7 to the desired spirostanol 2 was then completed under strong mineral acidic conditions (methanolic $\mathrm{HCl}$ ), as previous work highlighted the undesired isomerization at $C_{25}$ when weaker mineral acids (e.g., AcOH) were used [38]. Spirostanol 2 was obtained in 8.1:1 d.r. at $\mathrm{C}_{25}$ in favor of the desired $25-(S)$ diastereoisomer in $74 \%$ yield on a $1 \mathrm{~g}$ scale after recrystallization. The observed imperfect diastereoselectivity could be attributed to the loss of optical purity of the intermediate aldehyde of $\mathbf{1 5}$ during the Wittig olefination through uncontrolled racemization under the strong basic conditions.

After individually optimizing all the steps on a gram scale, we were able to streamline multiple steps to facilitate processing without compromising on either purity or yield (Scheme 5). We found that the protection, reduction, and dehydration sequence of 5 to 12 could be accomplished using crude intermediates in $65 \%$ yield on a $13 \mathrm{~g}$ scale and ultimately in $61 \%$ yield on a $46 \mathrm{~g}$ scale over three steps (avg. $85 \%$ / step), requiring only one silica pad after the third step. Minor decomposition products could be observed during the reduction step when the mixture warmed above $-65{ }^{\circ} \mathrm{C}$ on the $13 \mathrm{~g}$ scale batch. In consequence, we decided to divide the $46 \mathrm{~g}$ scale batch in two equal parts to maintain better internal temperature control of the cryogenic mixture. The handling of the air-sensitive ${ }^{i} \mathrm{Bu}_{2} \mathrm{AlH}$ did not prove to be a safety hazard at this scale. Since the next reaction proved to be a safety hazard, we limited the scale of the transformation according to the ${ }^{t} \mathrm{BuLi}$ reagent bottle size and concentration. Transfer by canulation of a single reagent container $(100 \mathrm{~mL})$ of ${ }^{t} \mathrm{BuLi}$ to the reaction mixture limited our exposure to the pyrophoric reagent, which is important to avert potential accidents on this scale. [39] The iodination, cross-coupling, and spiroketalization steps from 12 to 2 were also streamlined to afford the desired spiroketal in $44 \%$ yield over three steps (avg. $76 \%$ /step) on a $19 \mathrm{~g}$ scale after recrystallization directly from the reaction mixture.

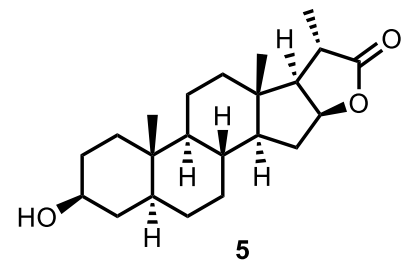

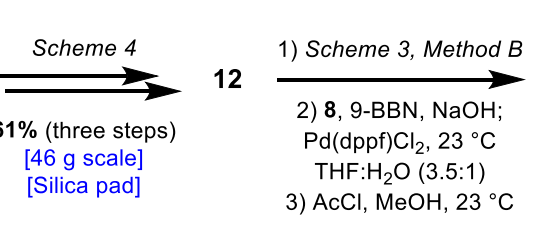

$\mathbf{4 4 \%}$ (three steps) [19 g scale] [Recrystallization]

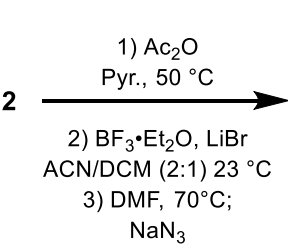

$\mathbf{9 3} \%$ (three steps) [9 g scale]

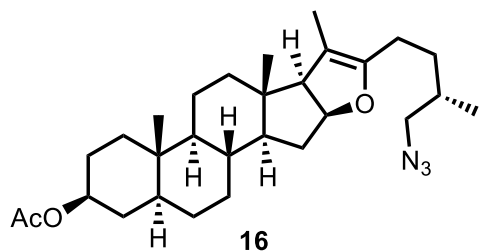

16

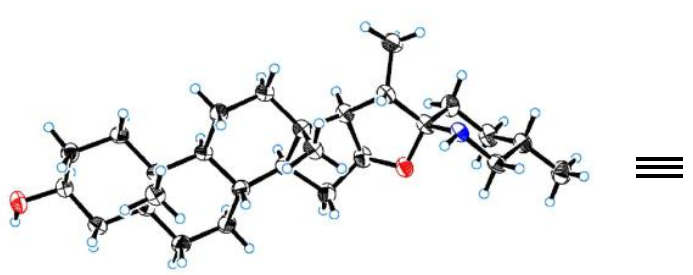

CCDC \#2090407

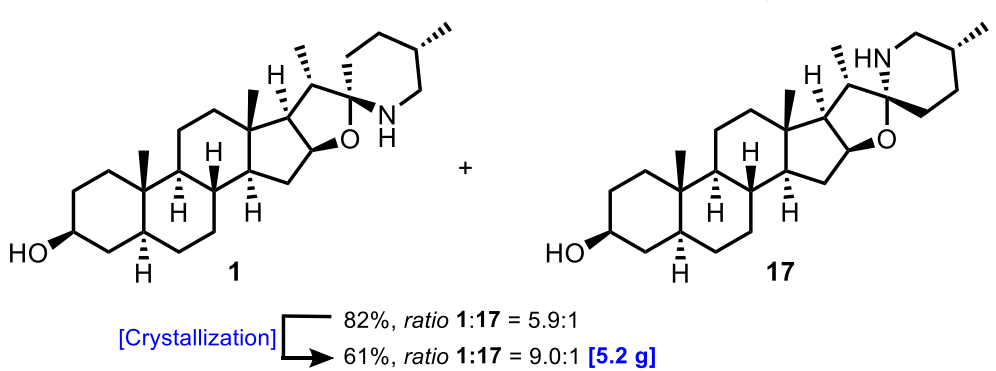

Scheme 5. Streamlined chemical steps and ORTEP diagram of $\mathbf{1 .}$

With a large quantity of the desired spiroketal 2 in hand, we applied our previously used successful endgame sequence of transformations with no complications [15]. Compound 2 was acetylated using $\mathrm{Ac}_{2} \mathrm{O}$ in pyridine and then subjected to Lewis acid-mediated spiroketal opening using $\mathrm{BF}_{3} \cdot \mathrm{Et}_{2} \mathrm{O}$ and $\mathrm{LiBr}$, followed by substitution using $\mathrm{NaN}_{3}$ in $\mathrm{DMF}$ to yield the desired azide 16 in 93\% yield over three steps (avg. 98\%/step) and high purity 
$(>99 \%)$ over three steps, requiring no purification. Subsequent reduction of the azide, followed by instant cyclization using TMSI (TMSCl/NaI) delivered the spiroaminoketal moiety, which, after ester hydrolysis $(\mathrm{NaOH})$, produced the natural product 1 in a 5.9:1 ratio with the undesired 5,6-dihydrosolasodine $\mathbf{1 7}$. The obtention of $\mathbf{1 7}$ as a minor product is a consequent of the unperfect diastereoselectivity in the obtention of $\mathbf{2}$ and the uncontrolled inversion of the $\mathrm{C}_{25}(\mathrm{~S} \rightarrow \mathrm{R})$ during the TMSI-mediated reduction of 16 [40]. Purification by crystallization (vapor diffusion, see Supplementary Materials) generated crystals of tomatidine in a 9.0:1 ratio of $\mathbf{1 : 1 7}$ in 61\% yield in two steps from azide $\mathbf{1 6}$ on a $10 \mathrm{~g}$ scale.

Overall, this sequence yielded 5.2 grams of tomatidine in a single batch, starting from $46 \mathrm{~g}$ of lactone 5 in $15.2 \%$ yield after 11 steps LLS (longest linear sequence). Another smaller-scale iteration of this sequence enabled us to produce a total of $>7.5$ grams of synthetic tomatidine in the laboratory. An analysis of a single crystal by $\mathrm{X}$-ray diffraction (XRD) unequivocally confirmed the identity of $\mathbf{1}$ (Scheme 5) as its methanol co-crystal.

\section{Experimental Section}

\subsection{General Remarks}

Unless otherwise stated, all reactions were performed using commercial reagents bought from Sigma-Aldrich (Oakville, Canada), TCI America (Portland, OR, USA), CombiBlocks (San Diego, CA, USA), Chem-Impex (Bensenville, IL, USA) and Strem Chemicals (Newburyport, MA, USA) without further purification and Teflon-coated stir bars. Reactions that required heating above room temperature $\left(23^{\circ} \mathrm{C}\right)$ were heated in an oil bath. Silica pads were performed using SiliaFlash ${ }^{\mathrm{TM}}$ P60 40 to $63 \mu \mathrm{m}$ thick silica gel from Silicycle. Thin layer chromatography (TLC) was performed on glass-backed Silicycle SiliaPlate F-254 precoated plates with a thickness of $250 \mu \mathrm{m}$ and a porosity of $60 \AA$. Compounds were visualized with UV light $(254 \mathrm{~nm})$, followed by staining with cerium ammonium molybdate (steroids) or potassium permanganate (nonsteroids) and heating. Nuclear magnetic resonance (NMR) spectra were obtained on a Bruker Ascend 400 spectrometer (Bruker, Ettlingen, Germany) and are reported in parts per million (ppm) for chemical shifts and hertz $(\mathrm{Hz})$ for coupling constants $(\mathrm{J})$. Residual chloroform $\left(\mathrm{CHCl}_{3}\right)$ signals were used as an internal reference for the ${ }^{1} \mathrm{H}(\delta=7.26 \mathrm{ppm})$ and ${ }^{13} \mathrm{C}(\delta=77.16 \mathrm{ppm})$ spectra. The following abbreviations are used to describe the NMR multiplicities: br $=$ broad, $\mathrm{s}=$ singlet, $\mathrm{d}=$ doublet, $\mathrm{t}=$ triplet, $\mathrm{q}=$ quartet, quint $=$ quintet, sext $=$ sextuplet, sept $=$ septuplet, and $\mathrm{m}=$ multiplet. For the ${ }^{1} \mathrm{H}$ NMR data of steroid intermediates, only assignable signals are listed. Infrared (FTIR) spectra were obtained on an ABB Bomem MB104 spectrophotometer (ABB Inc., Québec City, Canada) using a diamond-attenuated total reflectance (ATR) accessory. High-resolution mass spectra (HRMS) were obtained on a Nexera (Shimadzu) LC-QTOF mass spectrometer (Shimadzu Scientific Instruments, Columbia, MD, USA) coupled to a maXis (Bruker) mass spectrometer (ESI) using sodium formate as an internal standard. Melting points were measured on an Electrothermal MEL-TEMP 1101D melting point apparatus (Mettler-Toledo, Portland, OR, USA). XRD was performed on a KAPPA APEX-DUO (Bruker, Karlsruhe, Germany) diffractometer using a Cu radiation source.

\subsection{Methods}

3.2.1. Synthesis of (2S)-2-Methyl-3-((tetrahydro-2H-pyran-2-yl)oxy)propan-1-ol (15)

A $500 \mathrm{~mL}$ round-bottom flask was charged with a stir bar, DCM $(200 \mathrm{~mL}),(R)$-Roche ester 14 (24.9 g, $211 \mathrm{mmol}, 1.0$ eq.), and 3,4-dihydro-2H-pyran ( $26.9 \mathrm{~mL}, 295 \mathrm{mmol}, 1.4$ eq.). Pyridinium $p$-toluenesulfonate ( $2.65 \mathrm{~g}, 10.5 \mathrm{mmol}, 0.05$ eq.) was then added, and the mixture was stirred at room temperature. After $5 \mathrm{~h}$, the reaction was diluted with DCM $(200 \mathrm{~mL})$, and the organic phase was washed with water $(50 \mathrm{~mL})$. The organic phase was collected, and the aqueous phase was extracted with DCM $(3 \times 50 \mathrm{~mL})$. The combined organic layers were washed with brine $(25 \mathrm{~mL})$, dried over $\mathrm{Na}_{2} \mathrm{SO}_{4}$, and concentrated in vacuo to yield the crude THP ester as a colorless oil.

A $1 \mathrm{~L}$, two-neck round-bottom flask was charged with $\mathrm{Et}_{2} \mathrm{O}(175 \mathrm{~mL})$ and lithium aluminum hydride $(8.00 \mathrm{~g}, 211 \mathrm{mmol}, 1.0 \mathrm{eq}$.$) . A thermometer was fitted, and the suspension$ 
was vigorously stirred and cooled to $0^{\circ} \mathrm{C}$ using an ice bath. To this suspension was added a solution of the THP ester prepared above in $\mathrm{Et}_{2} \mathrm{O}(200 \mathrm{~mL}+50 \mathrm{~mL}$ wash $)$ via canulation at a slow rate that kept the internal temperature below $15^{\circ} \mathrm{C}$. After the canulation was complete, the mixture was warmed to room temperature and stirred overnight. The mixture was then cooled back to $0{ }^{\circ} \mathrm{C}$ and quenched by careful addition of sodium sulfate decahydrate ( $50.9 \mathrm{~g}, 158 \mathrm{mmol}, 0.75 \mathrm{eq}$.). The suspension was warmed to room temperature and stirred vigorously for $1 \mathrm{~h}$. Subsequently, this suspension was filtered using a Büchner funnel and concentrated in vacuo. The obtained residue was distilled under reduced pressure to yield monoprotected diol 15 (29.6 g, 81\% over two steps) as a colorless oil.

${ }^{1} \mathrm{H} \mathrm{NMR}\left(400 \mathrm{MHz}, \mathrm{CDCl}_{3}\right) \delta(\mathrm{ppm}) 4.55(\mathrm{t}, 1 \mathrm{H}, J=4.4 \mathrm{~Hz}), 3.86-3.79(\mathrm{~m}, 1 \mathrm{H}), 3.80$ $(\mathrm{q}, 0.5 \mathrm{H}, J=4.8 \mathrm{~Hz}), 3.64(\mathrm{dd}, 1 \mathrm{H}, J=9.6,8.4 \mathrm{~Hz}), 3.59-3.54(\mathrm{~m}, 1.5 \mathrm{H}), 3.53-3.47(\mathrm{~m}, 1 \mathrm{H})$, $3.44(\mathrm{q}, 0.5 \mathrm{H}, J=4.4 \mathrm{~Hz}), 3.34(\mathrm{dd}, 0.5 \mathrm{H}, J=9.2,5.2 \mathrm{~Hz}), 2.79-2.73(\mathrm{~m}, 1 \mathrm{H}), 2.05-1.95(\mathrm{~m}$, $1 \mathrm{H}), 1.80-1.64(\mathrm{~m}, 2 \mathrm{H}), 1.58-1.46(\mathrm{~m}, 4 \mathrm{H}), 0.89(\mathrm{dd}, 3 \mathrm{H}, J=6.8,4.4 \mathrm{~Hz}) .{ }^{13} \mathrm{C} \mathrm{NMR}(100 \mathrm{MHz}$, $\left.\mathrm{CDCl}_{3}\right) \delta(\mathrm{ppm}) 99.4,99.2,72.1,72.0,67.3,67.2,62.6,62.5,35.8,35.5,30.7,30.6,25.4,25.3$, 19.7, 13.7, 13.6. HRMS-ESI $(m / z)$ calcd for $\mathrm{C}_{9} \mathrm{H}_{18} \mathrm{O}_{3}: 197.1148[\mathrm{M}+\mathrm{Na}]^{+}$found: 197.1151 $[\mathrm{M}+\mathrm{Na}]^{+}$. FTIR-ATR (neat) $v\left[\mathrm{~cm}^{-1}\right] 3436,2941,2871,1739,1120,1020,973,900,867,813$. $\mathrm{R}_{\mathrm{f}} 0.45$ (50\% EtOAc/hexanes) $\left[\mathrm{KMnO}_{4}\right]$. Bp $135-140{ }^{\circ} \mathrm{C}(30 \mathrm{mmHg})$.

\subsubsection{Synthesis of 2-(((S)-2-Methylbut-3-en-1-yl)oxy)tetrahydro-2H-pyran (8)}

A mixture of pyridinium dichromate (75.6 g, $201 \mathrm{mmol}, 2.0 \mathrm{eq}$.) and silica gel (75.6 g) was ground to a fine powder using a mortar and pestle. This homogenous solid was then transferred to a $1 \mathrm{~L}$ round-bottom flask containing DCM $(200 \mathrm{~mL})$ and vigorously stirred using a large stir bar. A solution of 15 (17.5 g, $100 \mathrm{mmol}, 1.0$ eq.) in DCM (60 mL) was then added dropwise over $15 \mathrm{~min}$. This suspension was stirred at room temperature for $48 \mathrm{~h}$. The mixture was diluted with $\mathrm{Et}_{2} \mathrm{O}(500 \mathrm{~mL})$ and then filtered through a 2:1 silica gel/Celite ${ }^{\mathrm{TM}}$ pad. This mixture was subsequently concentrated in vacuo and coevaporated using tetrahydrofuran $(\mathrm{THF}, 3 \times 75 \mathrm{~mL}$ ) to obtain the corresponding aldehyde. In another $1 \mathrm{~L}$ round-bottom flask, a ${ }^{n}$ BuLi solution $(2.50 \mathrm{M}$ in hexanes, $100 \mathrm{~mL}, 251 \mathrm{mmol}, 2.5 \mathrm{eq}$.) was canulated into a suspension of methyltriphenylphosphonium bromide $(93.3 \mathrm{~g}, 261 \mathrm{mmol}$, 2.6 eq.) in anhydrous THF $(415 \mathrm{~mL})$ at $0{ }^{\circ} \mathrm{C}$. After stirring for $30 \mathrm{~min}$, this solution was cooled to $-78{ }^{\circ} \mathrm{C}$ and a solution of the crude aldehyde in THF $(100 \mathrm{~mL}+50 \mathrm{~mL}$ wash) was transferred via canulation. After $30 \mathrm{~min}$ at this temperature, the mixture was warmed to $0{ }^{\circ} \mathrm{C}$ and stirred for further $45 \mathrm{~min}$. The mixture was cooled back to $-78{ }^{\circ} \mathrm{C}$ and then quenched with sat. $\mathrm{NH}_{4} \mathrm{Cl}_{(\text {aq. }}(150 \mathrm{~mL})$. The mixture was slowly warmed to room temperature over $1 \mathrm{~h}$ and then transferred to an extraction funnel containing water $(250 \mathrm{~mL})$. The organic layer was collected, and the aqueous layer was extracted with EtOAc $(3 \times 200 \mathrm{~mL})$. The combined organic phases were washed with brine $(100 \mathrm{~mL})$, dried over $\mathrm{Na}_{2} \mathrm{SO}_{4}$, and concentrated in vacuo to produce a light-orange oil. The crude product was passed through a silica pad $(6 \mathrm{~cm} \times 10 \mathrm{~cm})$ using $20 \%$ EtOAc/hexanes $(1 \mathrm{~L})$ as an eluent. The filtrate was concentrated in vacuo to yield olefin 8 (10.6 g, 62\%, >95\% purity by NMR) as a light-yellow oil, which was used in the next step without further purification.

${ }^{1} \mathrm{H} \mathrm{NMR}\left(400 \mathrm{MHz} \mathrm{CDCl}_{3}\right) \delta(\mathrm{ppm}) 5.84-5.74(\mathrm{~m}, 1 \mathrm{H}), 5.04(\mathrm{dd}, 1 \mathrm{H}, J=8.8,1.2 \mathrm{~Hz})$, $4.98(\mathrm{dd}, 1 \mathrm{H}, J=5.2,1.2 \mathrm{~Hz}), 4.57(\mathrm{t}, 1 \mathrm{H}, J=3.6 \mathrm{~Hz}), 3.87-3.81(\mathrm{~m}, 1 \mathrm{H}), 3.58(\mathrm{ddd}, 1 \mathrm{H}$, $J=36.4,9.6,6.8 \mathrm{~Hz}$ ), 3.50-3.45 (m, 1H), 2.46 (quint, 1H, $J=6.8 \mathrm{~Hz}), 1.85-1.76(\mathrm{~m}, 1 \mathrm{H})$, 1.73-1.64 (m, 1H), 1.60-1.47 (m, 4H), $1.02(\mathrm{dd}, 3 \mathrm{H}, \mathrm{J}=6.8,4.4 \mathrm{~Hz}) .{ }^{13} \mathrm{C} \mathrm{NMR}(100 \mathrm{MHz}$, $\left.\mathrm{CDCl}_{3}\right) \delta(\mathrm{ppm}) 141.5,141.4,114.1,114.0,98.9,98.8,72.2,72.1,62.2,62.1,37.9,37.8,30.7,25.6$, 19.6, 16.8, 16.7. HRMS-ESI $(m / z)$ calcd for $\mathrm{C}_{10} \mathrm{H}_{18} \mathrm{O}_{2}: 193.1200[\mathrm{M}+\mathrm{Na}]^{+}$found: 193.1203 $[\mathrm{M}+\mathrm{Na}]^{+}$. FTIR-ATR (neat) $v\left[\mathrm{~cm}^{-1}\right]$ 2925, 2869, 1456, 1201, 1120, 1031, 973, 904, 869, 815. $\mathrm{R}_{\mathrm{f}} 0.50$ (5\% EtOAc/hexanes) $\left[\mathrm{KMnO}_{4}\right]$.

3.2.3. Synthesis of ( $2 a S, 4 S, 6 a S, 6 b S, 8 a S, 8 b R, 9 S, 11 a S, 12 a S, 12 b R)-4-(M e t h o x y m e t h o x y)-$ 6a,8a,9-trimethyloctadecahydro-10H-naphtho[2' $\left., 1^{\prime}: 4,5\right]$ indeno[2,1-b]furan-10-one (9a)

Dinorcholanic lactone 5 was prepared from commercial diosgenin (Chem Impex, Catalog No. 24131) by hydrogenation [41], B-V oxidation [20], and recrystallization from 
EtOAc. A 1 L, two-neck round-bottom flask was charged with a stir bar, 5 (43.7 g, 126 mmol, 1.0 eq.), tetrabutylammonium iodide (3.26 g, $8.82 \mathrm{mmol}, 0.07$ eq.), and DCM (375 mL). $\mathrm{N}$,N-Diisopropylethylamine $(30.7 \mathrm{~mL}, 176 \mathrm{mmol}, 1.4 \mathrm{eq}$.) was then added in one portion. A condenser and an addition funnel containing chloromethyl methyl ether $(11.5 \mathrm{~mL}$, $151 \mathrm{mmol}, 1.2$ eq.) in DCM (50 mL) were connected. The mixture was stirred for $10 \mathrm{~min}$ under a flow of $\mathrm{Ar}$, and the $\mathrm{MOMCl}$ solution was then added dropwise over $10 \mathrm{~min}$. Subsequently, the reaction mixture was heated to reflux. After $3 \mathrm{~h}$, the mixture was cooled down to room temperature, transferred to an extraction funnel, and washed with $1 \mathrm{~N}$ $\mathrm{HCl}_{(\text {aq. })}(150 \mathrm{~mL})^{*}$. The organic phase was collected, and the aqueous phase was extracted with DCM $(3 \times 100 \mathrm{~mL})$. The organic layers were combined, washed with brine $(50 \mathrm{~mL})$, dried over $\mathrm{Na}_{2} \mathrm{SO}_{4}$, and then concentrated in vacuo to yield MOM lactone 9a (49.1 g, $>99 \%$ purity by NMR) as a light-brown solid, which was used in the next step without purification.

${ }^{*}$ NOTE: Vigorous gas build-up, vent frequently.

${ }^{1} \mathrm{H}$ NMR $\left(400 \mathrm{MHz}, \mathrm{CDCl}_{3}\right) \delta(\mathrm{ppm}) 4.92(\mathrm{dt}, 1 \mathrm{H}, J=4.8,7.6 \mathrm{~Hz}), 4.66(\mathrm{~s}, 2 \mathrm{H}), 3.47$ (sept, 1H, J = 4.8 Hz), $3.35(\mathrm{~s}, 3 \mathrm{H}), 2.56(\mathrm{q}, 1 \mathrm{H}, J=7.6 \mathrm{~Hz}), 2.25$ (quint, $1 \mathrm{H}, J=7.2 \mathrm{~Hz}), 1.84$ $(\mathrm{d}, 1 \mathrm{H}, J=7.6 \mathrm{~Hz}), 1.30(\mathrm{~d}, 3 \mathrm{H}, J=7.6 \mathrm{~Hz}), 0.81(\mathrm{~s}, 3 \mathrm{H}), 0.73(\mathrm{~s}, 3 \mathrm{H}) .{ }^{13} \mathrm{C} \mathrm{NMR}(100 \mathrm{MHz}$, $\left.\mathrm{CDCl}_{3}\right) \delta$ (ppm) 181.5, 94.7, 82.9, 76.3, 59.2, 55.3, 54.7, 54.5, 44.9, 41.9, 38.5, 37.1, 36.2, 35.9, $35.3,34.9,33.1,32.3,28.8,28.6,20.6,18.1,14.0,12.4$. HRMS-ESI $(m / z)$ calcd for $\mathrm{C}_{24} \mathrm{H}_{38} \mathrm{O}_{4}$ : $413.2662[\mathrm{M}+\mathrm{Na}]^{+}$found: $413.2660[\mathrm{M}+\mathrm{Na}]^{+}$. FTIR-ATR (neat) $v\left[\mathrm{~cm}^{-1}\right] 2927,2873$, $2844,1755,1454,1188,1105,1029,879,671,628 . R_{\mathrm{f}} 0.45$ (20\% EtOAc/hexanes) [CAM]. Mp $143-145^{\circ} \mathrm{C}$.

3.2.4. Synthesis of ( $2 a S, 4 S, 6 a S, 6 b S, 8 a S, 8 b R, 9 S, 11 a S, 12 a S, 12 b R)-4-(M e t h o x y m e t h o x y)-$ 6a,8a,9-trimethyloctadecahydro-1H-naphtho[2', $\left.1^{\prime}: 4,5\right]$ indeno[2,1-b]furan-10-ol (11)

Two $1 \mathrm{~L}$, two-neck round-bottom flasks were each fitted with a stir bar and a thermometer. The flasks were then charged with crude 9a (23.2 g, 59.5 mmol, 1.0 eq. $)$ and purged of air and moisture by alternately applying vacuum and $\mathrm{Ar}_{(\mathrm{g})}$ in combination with torching (three cycles). Anhydrous DCM $(240 \mathrm{~mL})$ was then added and the mixture was cooled to $-78^{\circ} \mathrm{C}$ using a dry ice/acetone bath. A diisobutylaluminium hydride solution (1 $\mathrm{M}$ in DCM, $71.4 \mathrm{~mL}, 71.4 \mathrm{mmol}, 1.2$ eq.) was then added dropwise to each flask at a slow rate to ensure the temperature was maintained below $-70{ }^{\circ} \mathrm{C}$. Once the addition was complete, the resultant solutions were further stirred for $15 \mathrm{~min}$ at this temperature and subsequently quenched by dropwise addition of EtOH $(8 \mathrm{~mL})$. The mixtures were allowed to warm to room temperature and sat. sodium potassium tartrate tetrahydrate ${ }_{(\text {aq. }}(150 \mathrm{~mL})$ was added, followed by vigorously stirring overnight. The mixtures were then combined in an extraction funnel containing water $(300 \mathrm{~mL})$. The organic layer was collected, and the aqueous layer was extracted with DCM $(4 \times 150 \mathrm{~mL})$. The combined organic phases were washed with brine $(100 \mathrm{~mL})$, dried over $\mathrm{Na}_{2} \mathrm{SO}_{4}$, and then concentrated in vacuo to yield MOM hemiacetal 11 (46.4 $\mathrm{g}, 90-92 \%$ purity by NMR) as a light-brown foam in an inconsequential 2:1 mixture of diastereoisomers, which was used directly in the next step without purification. A small sample $(30 \mathrm{mg}$ ) was purified by preparative TLC to collect analytical data.

${ }^{1} \mathrm{H}$ NMR (400 MHz, $\left.\mathrm{CDCl}_{3}\right) \delta(\mathrm{ppm}) 5.46-5.45\left(\mathrm{~d}, 0.66 \mathrm{H}, 22-\mathrm{H}_{\text {maj }}, J=3.6 \mathrm{~Hz}\right), 4.87$ $\left(\mathrm{t}, 0.33 \mathrm{H}, 22-\mathrm{H}_{\min }, J=5.6 \mathrm{~Hz}\right), 4.72-4.65\left(\mathrm{~m}, 0.66 \mathrm{H}, 16-\mathrm{H}_{\mathrm{maj}}\right), 4.67(\mathrm{~s}, 2 \mathrm{H}), 4.35(\mathrm{dt}, 0.33 \mathrm{H}$, $16-\mathrm{H}_{\text {min }}, J=6.0,8.0 \mathrm{~Hz}$ ), 3.48 (sept. $1 \mathrm{H}, J=6.4 \mathrm{~Hz}$ ), $3.36(\mathrm{~s}, 3 \mathrm{H}), 3.00$ (br s, 0.32H, 22-OH $\mathrm{Hin}_{\text {min }}$ ), 2.45 (br s, 0.66H, 22- $\mathrm{OH}_{\text {maj }}$ ), 2.26 (sext, 0.66H, 20- $\mathrm{H}_{\text {maj }} J=7.2 \mathrm{~Hz}$ ), 2.06-1.97 (m, 1H), 1.90 (sext, 0.33H, 20- $\left.\mathrm{H}_{\min }, J=6.8 \mathrm{~Hz}\right), 1.09\left(\mathrm{~d}, 1 \mathrm{H}, \mathrm{H}_{\min }-\mathrm{C}_{21}, J=7.2 \mathrm{~Hz}\right), 1.04\left(\mathrm{~d}, 2 \mathrm{H}, \mathrm{H}_{\mathrm{maj}}-\mathrm{C}_{21}\right.$, $J=7.2 \mathrm{~Hz}), 0.87\left(\mathrm{~s}, 1 \mathrm{H}, \mathrm{H}_{\min }-\mathrm{C}_{18}\right), 0.82\left(\mathrm{~s}, 1 \mathrm{H}, \mathrm{H}_{\min }-\mathrm{C}_{19}\right), 0.81\left(\mathrm{~s}, 2 \mathrm{H}, \mathrm{H}_{\text {maj }}-\mathrm{C}_{18}\right), 0.76(\mathrm{~s}, 2 \mathrm{H}$, $\left.\mathrm{H}_{\text {maj }}-\mathrm{C}_{19}\right) .{ }^{13} \mathrm{C}$ NMR $\left(100 \mathrm{MHz}, \mathrm{CDCl}_{3}\right) \delta$ (ppm) 108.4, 103.3, 94.6, 82.3, 80.4, 76.3, 62.7, 62.1, $56.4,56.1,55.2,54.5,54.4,44.9,41.3,40.9$, 39.9, 39.8, 37.1, 37.08, 37.06, 35.8, 35.3, 35.2, 35.1, $32.7,32.3,32.2,28.7,21.0,20.9,18.2,16.7,16.2,14.9,12.4,12.3$. HRMS-ESI $(\mathrm{m} / \mathrm{z})$ calcd for $\mathrm{C}_{24} \mathrm{H}_{40} \mathrm{O}_{4}: 415.2819[\mathrm{M}+\mathrm{Na}]^{+}$found: $415.2811[\mathrm{M}+\mathrm{Na}]^{+}$. FTIR-ATR (neat) $v\left[\mathrm{~cm}^{-1}\right] 3388$, 
2927, 2846, 1448, 1379, 1143, 1105, 1039, 985, 929. R 0.30 (20\% EtOAc/hexanes) [CAM]. Mp $133-135{ }^{\circ} \mathrm{C}$.

3.2.5. Synthesis of

(2aS,4S,6aS,6bS,8aS,8bS,11aS,12aS,12bR)-4-(Methoxymethoxy)-6a,8a,9-trimethyl

2,2a,3,4,5,6,6a,6b,7,8,8a,8b,11a,12,12a

12b-hexadecahydro-1H-naphtho[2', $\left.1^{\prime}: 4,5\right]$ indeno[2,1-b]furan (12)

A $1 \mathrm{~L}$, two-neck round-bottom flask was charged with a stir bar and crude $\mathbf{1 1}$ (46.4 g, $119 \mathrm{mmol}, 1.0 \mathrm{eq}$.). Toluene $(475 \mathrm{~mL})$ and freshly distilled triethylamine $(133 \mathrm{~mL}, 954 \mathrm{mmol}$, 8.0 eq.) were added, and the flask was fitted with a reflux condenser and an addition funnel containing freshly distilled methanesulfonyl chloride (36.9 mL, $477 \mathrm{mmol}, 4.0$ eq.). The flask was then stirred under a flow of $\mathrm{Ar}_{(\mathrm{g})}$ for $10 \mathrm{~min}$, followed by dropwise addition of $\mathrm{MsCl}$ over $15 \mathrm{~min}^{*}$. After the addition was complete, the mixture was stirred at $100{ }^{\circ} \mathrm{C}$ for $16 \mathrm{~h}$. The mixture was then cooled to room temperature, followed by a second addition of triethylamine $(33.2 \mathrm{~mL}, 238 \mathrm{mmol}, 2.0 \mathrm{eq})$ and methanesulfonyl chloride $(9.23 \mathrm{~mL}$, $119 \mathrm{mmol}, 1.0$ eq.). This mixture was then further stirred for $3 \mathrm{~h}$ at $100{ }^{\circ} \mathrm{C}$. The mixture was then cooled to room temperature, quenched with sat. $\mathrm{NH}_{4} \mathrm{Cl}_{(\text {aq. }}(200 \mathrm{~mL})$, and vigorously stirred for $30 \mathrm{~min}$. The mixture was subsequently transferred to an extraction funnel containing water $(400 \mathrm{~mL})$ and extracted with EtOAc $(4 \times 300 \mathrm{~mL})$. The organic layers were combined and washed with brine $(100 \mathrm{~mL})$, dried over $\mathrm{Na}_{2} \mathrm{SO}_{4}$, and then concentrated in vacuo to yield a dark brown oil, which was passed through a silica pad $(6 \mathrm{~cm} \times 14 \mathrm{~cm})$ using 10\% EtOAc/hexanes (2 L) as an eluent. The filtrate was then concentrated in vacuo to yield enol ether 12 (27.3 $\mathrm{g}, 61 \%$, three steps) as an off-white solid.

${ }^{*} \mathrm{NOTE}$ : Strong exothermic reaction.

${ }^{1} \mathrm{H}$ NMR $\left(400 \mathrm{MHz}, \mathrm{CDCl}_{3}\right) \delta(\mathrm{ppm}) 6.00(\mathrm{~s}, 1 \mathrm{H}), 4.88-4.82(\mathrm{~m}, 1 \mathrm{H}), 4.68(\mathrm{~s}, 2 \mathrm{H}), 3.49$ (sept, 1H, J = 4.8 Hz), $3.36(\mathrm{~s}, 3 \mathrm{H}), 2.44(\mathrm{~d}, 1 \mathrm{H}, J=10.4 \mathrm{~Hz}), 2.20-2.13(\mathrm{~m}, 1 \mathrm{H}), 1.61(\mathrm{~s}, 3 \mathrm{H})$, 0.82 (s, 3H), 0.71 (s, 3H). ${ }^{13} \mathrm{C} \mathrm{NMR}\left(100 \mathrm{MHz} \mathrm{CDCl}_{3}\right) \delta(\mathrm{ppm}) 141.0,111.1,94.7,87.3,76.4$, 63.0, 55.3, 54.9, 54.5, 45.0, 43.3, 39.8, 37.2, 35.9, 35.4, 35.0, 34.2, 32.6, 28.9, 28.8, 21.3, 14.3, 12.4, 11.5. HRMS-ESI $(m / z)$ calcd for $\mathrm{C}_{24} \mathrm{H}_{38} \mathrm{O}_{3}: 397.2713[\mathrm{M}+\mathrm{Na}]^{+}$found: $397.2708[\mathrm{M}+\mathrm{Na}]^{+}$. FTIR-ATR (neat) $v\left[\mathrm{~cm}^{-1}\right] 2935,2879,1144,1379,1103,1085,1045,931,914,848,617 . \mathrm{R}_{\mathrm{f}}$ 0.50 (10\% EtOAc/hexanes) [CAM]. Mp $120-122{ }^{\circ} \mathrm{C}$.

3.2.6. Synthesis of ( $2 a \mathrm{a}, 4 \mathrm{~S}, 6 \mathrm{aS}, 6 \mathrm{bS}, 8 \mathrm{aS}, 8 \mathrm{bS}, 11 \mathrm{aS}, 12 \mathrm{aS}, 12 \mathrm{bR})-10-$-Iodo-4-(methoxymethoxy)6a,8a,9-trimethyl-2,2a,3,4,5,6,6a,6b,7,8,8a,8b,11a, 12,12a,12b-hexadecahydro-1H-naphtho[ $\left.2^{\prime}, 1^{\prime}: 4,5\right]$ indeno[2,1-b]furan (13)

A 1 L round-bottom flask was charged with 12 (18.8 g, $50.2 \mathrm{mmol}, 1.0$ eq.) and a stir bar*. The flask was purged of air and moisture by alternately applying vacuum and $\operatorname{Ar}_{(\mathrm{g})}$ (three cycles) in combination with torching. Anhydrous THF (100 mL) was then added, and the mixture was cooled to $-78^{\circ} \mathrm{C}$ in a dry ice/acetone bath. Freshly titrated [42] ${ }^{t} \mathrm{BuLi}$ (1.50 M in pentane, $100 \mathrm{~mL}, 151 \mathrm{mmol}, 3.0$ eq.) was then transferred to the chilled flask via canulation over $15 \mathrm{~min}$. This mixture was stirred for $5 \mathrm{~min}$ at $-78^{\circ} \mathrm{C}$ and then warmed to $0^{\circ} \mathrm{C}$ using an ice bath. After $30 \mathrm{~min}$ at this temperature, the flask was placed back in the dry ice/acetone bath and cooled to $-78^{\circ} \mathrm{C}$.

Under Ar atmosphere, a $250 \mathrm{~mL}$ round-bottom flask was charged with freshly purified [43] 1,2-diiodoethane (42.5 g, $151 \mathrm{mmol}, 3.0$ eq.) and dissolved in anhydrous THF (100 mL $+10 \mathrm{~mL}$ wash). This solution was then added to the lithiated enol ether flask by canulation over $15 \mathrm{~min}$. After the addition, the cooling bath was replaced with a room temperature water bath, and the reaction was allowed to proceed for $1 \mathrm{~h}$ as the mixture slowly developed a deep purple color. Sat. $\mathrm{Na}_{2} \mathrm{~S}_{2} \mathrm{O}_{3(\mathrm{aq})}(250 \mathrm{~mL})$ was then added to the flask and stirred vigorously. After $15 \mathrm{~min}$, this mixture was transferred to an extraction funnel containing water $(300 \mathrm{~mL})$. The organic layer was collected, and the aqueous layer was extracted with EtOAc $(3 \times 200 \mathrm{~mL})$. The organic layers were combined, washed with brine $(75 \mathrm{~mL})$, dried over $\mathrm{Na}_{2} \mathrm{SO}_{4}$, and concentrated in vacuo. The product was passed through a silica pad $(6 \mathrm{~cm} \times 12 \mathrm{~cm})$ using $15 \%$ EtOAc/hexanes $(2 \mathrm{~L})$ as an eluent to yield iodo enol ether 13 (24.7 g) as a light-yellow solid following concentration, which was used 
immediately in the next step. NMR analysis of the crude mixture showed $99 \%$ conversion of the starting material [44].

*NOTE: 13 was shielded from light at all times. 13 was found to be unstable even when stored under $\operatorname{Ar}_{(\mathrm{g})}$ in a dark cold freezer after one week and needs to be consumed directly after it is synthesized. After being stored for $24 \mathrm{~h}$ in $\mathrm{CDCl}_{3}$ in an NMR tube at room temperature, $\mathbf{1 3}$ underwent decomposition, and the solution in the tube turned to a dark purple color.

${ }^{1} \mathrm{H}$ NMR (400 MHz, $\left.\mathrm{CDCl}_{3}\right) \delta(\mathrm{ppm})$ 4.97-4.91 (m, 1H), 4.65 (s, 2H), 3.47 (sept, 1H, $J=4.8 \mathrm{~Hz}$ ), $3.34(\mathrm{~s}, 3 \mathrm{H}), 2.43(\mathrm{~d}, 1 \mathrm{H}, J=10.0 \mathrm{~Hz}), 2.18$ (quint, $1 \mathrm{H}, J=6.0 \mathrm{~Hz}$ ), 1.63 (s, $3 \mathrm{H}), 0.80(\mathrm{~s}, 3 \mathrm{H}), 0.66(\mathrm{~s}, 3 \mathrm{H}) .{ }^{13} \mathrm{C} \mathrm{NMR}\left(100 \mathrm{MHz}, \mathrm{CDCl}_{3}\right) \delta(\mathrm{ppm}) 117.3,100.0,94.3,88.5$, 76.2, 62.4, 55.2, 54.3, 54.2, 44.9, 44.0, 39.4, 37.1, 35.8, 35.3, 34.9, 32.5, 28.8, 28.7, 21.2, 14.6, 14.3, 12.4 HRMS-ESI $(\mathrm{m} / \mathrm{z})$ calcd for $\mathrm{C}_{24} \mathrm{H}_{37} \mathrm{O}_{7} \mathrm{I}: 501.1860[\mathrm{M}+\mathrm{H}]^{+}$found: $501.1853[\mathrm{M}+\mathrm{H}]^{+}$. FTIR-ATR (neat) $v\left[\mathrm{~cm}^{-1}\right]$ 2925, 2850, 1446, 1384, 1107, 1047, 1033, 906, 833, 725, 619. $\mathrm{R}_{\mathrm{f}}$ 0.48 (10\% EtOAc/hexanes) [UV, CAM]. Mp $123-125^{\circ} \mathrm{C}$.

3.2.7. Synthesis of ( $2 a \mathrm{~S}, 4 \mathrm{~S}, 6 \mathrm{aS}, 6 \mathrm{bS}, 8 \mathrm{aS}, 8 \mathrm{bS}, 11 \mathrm{aS}, 12 \mathrm{aS}, 12 \mathrm{bR})-4-($ Methoxymethoxy)-6a,8a,9trimethyl-10-((3S)-3-methyl-4-((tetrahydro-2H-pyran-2-yl)oxy)butyl)-

2,2a,3,4,5,6,6a,6b,7,8,8a,8b,11a,12,12a,12b-hexadecahydro-1H-

naphtho[ $\left.2^{\prime}, 1^{\prime}: 4,5\right]$ indeno[2,1-b]furan (7)

A 1 L round-bottom flask was charged with 8 (12.8 g, $75.2 \mathrm{mmol}, 1.5$ eq.) and a stir bar. The flask was purged of air and moisture by alternately applying vacuum and $\operatorname{Ar}_{(\mathrm{g})}$ (three cycles), and anhydrous THF $(300 \mathrm{~mL})$ was then added. A 9-borabicyclo[3.3.1]nonane solution (0.5 M in THF, $300 \mathrm{~mL}, 150 \mathrm{mmol}, 3.0$ eq.) was added dropwise over $30 \mathrm{~min}$. The resulting mixture was stirred for $3 \mathrm{~h}$ at room temperature. Then, $\mathrm{NaOH}_{(\text {aq. }}(1 \mathrm{M}, 150 \mathrm{~mL}$, $150 \mathrm{mmol}, 3.0$ eq.) was added carefully, and the mixture was stirred for a further $30 \mathrm{~min}$ at room temperature to prepare intermediate alkylborane 6 .

Meanwhile, a 3 L flask was charged with crude $\mathbf{1 3}$ and a stir bar, followed by a 3:1 $\mathrm{THF} / \mathrm{H}_{2} \mathrm{O}$ mixture $(500 \mathrm{~mL})$. [1,1'-Bis(diphenyl-phosphino)ferrocene]dichloropalladium (II) complex with dichloromethane $(8.19 \mathrm{~g}, 10.0 \mathrm{mmol}, 0.2 \mathrm{eq}$.) was added in one portion and then stirred under $\operatorname{Ar}_{(\mathrm{g})}$ for $10 \mathrm{~min}$. The hydroboration reaction mixture was then canulated to the main reaction over $15 \mathrm{~min}$ in a final $\mathrm{THF} / \mathrm{H}_{2} \mathrm{O}$ ratio of 3.5:1. After the transfer was complete, the mixture, which turned from bright red to dark brown upon addition of the alkylborane solution, was stirred at room temperature. After $5 \mathrm{~h}$, a TLC analysis of the reaction showed full consumption of $\mathbf{1 3}$. Hexanes $(800 \mathrm{~mL})$ were then added, and the resulting suspension was filtered through a 1:1 Celite ${ }^{\mathrm{TM}} /$ silica gel pad, which was further washed with $20 \%$ EtOAc/hexanes $(300 \mathrm{~mL})$. The filtrates were combined and added to an extraction funnel containing water $(600 \mathrm{~mL})$. The organic layer was collected, and the aqueous layer was extracted with EtOAc $(1 \times 200 \mathrm{~mL})$. The organic layers were combined, washed with brine $(150 \mathrm{~mL})$, dried over $\mathrm{Na}_{2} \mathrm{SO}_{4}$, and concentrated in vacuo to obtain a brown oil. The crude material was passed through a silica pad $(6 \mathrm{~cm} \times 12 \mathrm{~cm})$ using $20 \%$ EtOAc/hexanes $(1.5 \mathrm{~L})$ as an eluent. The filtrate was concentrated in vacuo to yield adduct $7(26.1 \mathrm{~g})$ as a light-brown pasty solid, which was used immediately in the next step. A small sample (35 $\mathrm{mg}$ ) was purified by preparative TLC to collect analytical data.

${ }^{1} \mathrm{H} \mathrm{NMR}\left(400 \mathrm{MHz}, \mathrm{CDCl}_{3}\right) \delta(\mathrm{ppm}) 4.73-4.64(\mathrm{~m}, 1 \mathrm{H}), 4.66(\mathrm{~s}, 2 \mathrm{H}), 4.55(\mathrm{~s}, 1 \mathrm{H})$, $3.87-3.81(\mathrm{~m}, 1 \mathrm{H}), 3.95(\mathrm{dd}, 0.5 \mathrm{H}, J=9.6,6.0 \mathrm{~Hz}), 3.52-3.43(\mathrm{~m}, 2.5 \mathrm{H}), 3.22(\mathrm{dd}, 0.5 \mathrm{H}, J=9.2$, $5.6 \mathrm{~Hz}), 3.13(\mathrm{dd}, 0.5 \mathrm{H}, J=9.6,6.8 \mathrm{~Hz}), 2.43(\mathrm{~d}, 1 \mathrm{H}, J=10.0 \mathrm{~Hz}), 2.16-2.05(\mathrm{~m}, 3 \mathrm{H}), 1.56(\mathrm{~s}$, $3 \mathrm{H}), 0.93(\mathrm{dd}, 3 \mathrm{H}, J=6.8,5.2 \mathrm{~Hz}), 0.81(\mathrm{~s}, 3 \mathrm{H}), 0.65(\mathrm{~s}, 3 \mathrm{H}) .{ }^{13} \mathrm{C} \mathrm{NMR}\left(100 \mathrm{MHz}, \mathrm{CDCl}_{3}\right) \delta$ (ppm) 152.0, 151.9, 103.6, 103.6, 99.1, 98.8, 94.6, 84.4, 76.4, 72.9, 72.8, 64.5, 62.2, 62.1, 55.2, $54.9,54.5,44.9,43.7,39.9,37.2,35.8,35.4,35.0,34.2,33.3,33.2,32.6,32.2,31.3,30.8,28.8$, 26.4, 25.7, 23.6, 23.5, 22.1, 21.3, 19.6, 17.2, 17.1, 14.3, 12.4, 11.8. HRMS-ESI $(\mathrm{m} / \mathrm{z}) \mathrm{calcd}$ for $\mathrm{C}_{34} \mathrm{H}_{56} \mathrm{O}_{5}: 567.4020[\mathrm{M}+\mathrm{Na}]^{+}$found: 567.4015 [M+Na] ${ }^{+}$. FTIR-ATR (neat) $v$ [cm $\left.^{-1}\right] 2925$, 2848, 1448, 1380, 1107, 1033, 975, 904, 867, 815. $\mathrm{R}_{\mathrm{f}} 0.65$ (15\% EtOAc/hexanes). Mp 78-80 ${ }^{\circ} \mathrm{C}$. 


\subsubsection{Synthesis of $(3 \beta, 5 \alpha, 25 S)$-Spirostan-3-ol (2)}

A $1 \mathrm{~L}$ round-bottom flask was charged with crude 7 and a stir bar, followed by addition of $\mathrm{MeOH}(390 \mathrm{~mL})$. The solution was adjusted to $\mathrm{pH} 1$ by careful addition of acetyl chloride (5.34 mL, $75.2 \mathrm{mmol}, 1.5$ eq.), and the resulting mixture was stirred at room temperature. After $30 \mathrm{~h}$, a thick white precipitate was formed, and an NMR analysis of the crude mixture showed full conversion of the starting material and its intermediates. The crude mixture was then transferred to an Erlenmeyer, recrystallized directly from the reaction mixture, and filtered through a Büchner funnel to yield 2 (9.15 g, 44\%, three steps) as a white solid with an 8.1:1 d.r. at $\mathrm{C}_{25}$ *

${ }^{*}$ NOTE: Only the major $\mathrm{C}_{25}$ isomer was characterized. The diastereoisomeric ratio was calculated by integrating $2(\mathrm{~d}, \delta=3.29 \mathrm{ppm})$ and 25 -epi-2 $(\mathrm{t}, \delta=3.37 \mathrm{ppm}){ }^{38}$ See Supplementary Materials.

${ }^{1} \mathrm{H}$ NMR $\left(400 \mathrm{MHz}, \mathrm{CDCl}_{3}\right) \delta(\mathrm{ppm}) 4.39(\mathrm{q}, 1 \mathrm{H}, J=7.2 \mathrm{~Hz}), 3.94(\mathrm{dd}, 1 \mathrm{H}, J=10.8$, $2.4 \mathrm{~Hz}$ ), $3.58(\mathrm{sept}, 1 \mathrm{H}, J=4.8 \mathrm{~Hz}), 3.29(\mathrm{~d}, 1 \mathrm{H}, J=11.2 \mathrm{~Hz}), 1.07(\mathrm{~d}, 3 \mathrm{H}, J=7.2 \mathrm{~Hz}), 0.98$ $(\mathrm{d}, 3 \mathrm{H}, J=6.8 \mathrm{~Hz}), 0.81(\mathrm{~s}, 3 \mathrm{H}), 0.75(\mathrm{~s}, 3 \mathrm{H}) .{ }^{13} \mathrm{C} \mathrm{NMR}\left(100 \mathrm{MHz}, \mathrm{CDCl}_{3}\right) \delta(\mathrm{ppm}) 109.7$, $81.1,71.4,65.3,62.2,56.4,54.5,44.9,42.3,40.7,40.2,38.3,37.1,35.7,35.3,32.4,31.7,31.6,28.7$, 27.2, 26.1, 25.9, 21.2, 16.6, 16.2, 14.5, 12.5. HRMS-ESI $(\mathrm{m} / \mathrm{z})$ calcd for $\mathrm{C}_{27} \mathrm{H}_{44} \mathrm{O}_{3}: 439.3183$ $[\mathrm{M}+\mathrm{Na}]^{+}$found: $439.3173[\mathrm{M}+\mathrm{Na}]^{+}$. FTIR-ATR (neat) $v\left[\mathrm{~cm}^{-1}\right]$ 3523, 3386, 2929, 2846, $1448,1369,1172,1047,981,918,850 . \mathrm{R}_{\mathrm{f}} 0.50$ (30\% EtOAc/hexanes) [CAM]. Mp 194-197 ${ }^{\circ} \mathrm{C}$ [lit. 197-203 ${ }^{\circ} \mathrm{C}$ ] [45]. The spectroscopic data were in agreement with previously reported data [38].

3.2.9. Synthesis of ( $2 \mathrm{aS}, 4 \mathrm{~S}, 6 \mathrm{aS}, 6 \mathrm{bS}, 8 \mathrm{aS}, 8 \mathrm{bS}, 11 \mathrm{aS}, 12 \mathrm{aS}, 12 \mathrm{bR})-10-((\mathrm{S})-4-$ Azido-3-methylbutyl)6a,8a,9-trimethyl-2,2a,3,4,5,6,6a,6b,7,8,8a,8b,11a,12,12a,12b-hexadecahydro-1Hnaphtho[2', $\left.1^{\prime}: 4,5\right]$ indeno[2,1-b]furan-4-yl acetate (16)

A $250 \mathrm{~mL}$ round-bottom flask was charged with $2(9.15 \mathrm{~g}, 27.8 \mathrm{mmol}, 1.0$ eq.) and pyridine $(87 \mathrm{~mL})$. This mixture was warmed to $50{ }^{\circ} \mathrm{C}$, and acetic anhydride $(16.6 \mathrm{~mL}, 176$ mmol, 8.0 eq.) was then added in one portion. After $2 \mathrm{~h}$ at this temperature, the mixture was poured into a $1 \mathrm{~L}$ Erlenmeyer containing ice-cold water $(500 \mathrm{~mL})$ and a stir bar. This suspension was vigorously stirred for $15 \mathrm{~min}$ and filtered using a Büchner funnel. The resulting pasty solid was then collected and dried under high vacuum overnight to yield OAc-2 (10.1 g) as a white fluffy solid.

A $1 \mathrm{~L}$, two-neck round-bottom flask was charged with crude OAc-2, lithium bromide (19.1 g, $220 \mathrm{mmol}, 10.0$ eq.), and a stir bar. This flask was purged of air and moisture by alternately applying vacuum and $\operatorname{Ar}_{(\mathrm{g})}$ (three cycles)* ${ }^{*}$ DCM $(190 \mathrm{~mL})$ and anhydrous acetonitrile $(95 \mathrm{~mL})$ were then added, and the mixture was stirred vigorously before adding $\mathrm{BF}_{3} \cdot \mathrm{Et}_{2} \mathrm{O}(27.2 \mathrm{~mL}, 220 \mathrm{mmol}, 10.0$ eq.) dropwise over $10 \mathrm{~min}$ at room temperature. After $3 \mathrm{~h}$, sat. $\mathrm{NaHCO}_{3 \text { (aq.) }}(50 \mathrm{~mL})$ was slowly added, followed by water $(200 \mathrm{~mL})$. This mixture was transferred to an extraction funnel, the organic layer was collected, and the aqueous layer was extracted with DCM $(3 \times 100 \mathrm{~mL})$. The organic layers were combined, washed with brine $(40 \mathrm{~mL})$, dried over $\mathrm{Na}_{2} \mathrm{SO}_{4}$, and concentrated in vacuo. The crude mixture was then transferred to a $250 \mathrm{~mL}$ round-bottom flask, dissolved in DMF $(95 \mathrm{~mL})$, and heated to $70{ }^{\circ} \mathrm{C}$. After stirring for $2 \mathrm{~h}$ at this temperature, sodium azide $(4.29 \mathrm{~g}, 66.1 \mathrm{mmol}, 3.0$ eq.) was added, and the mixture was stirred for further $3 \mathrm{~h}$ at $70^{\circ} \mathrm{C}$. Subsequently, the mixture was cooled to room temperature, transferred to an extraction funnel containing water $(300 \mathrm{~mL})$, and extracted with DCM $(4 \times 100 \mathrm{~mL})$. The organic layers were combined, washed with brine (100 mL), dried over $\mathrm{Na}_{2} \mathrm{SO}_{4}$, and then concentrated in vacuo to yield $\mathbf{1 6}$ ( $9.91 \mathrm{~g}, 93 \%$ over three steps, $>99 \%$ purity by NMR) as a beige waxy solid. This material was used directly in the next step without purification.

${ }^{*}$ NOTE: Glass vacuum adaptors were used to keep the mixture under $\operatorname{Ar}_{(\mathrm{g})}$ during the reaction $-\mathrm{BF}_{3} \cdot \mathrm{Et}_{2} \mathrm{O}$ corroded and clogged regular needles.

OAc-2: ${ }^{1} \mathrm{H} \mathrm{NMR}^{*}\left(400 \mathrm{MHz}, \mathrm{CDCl}_{3}\right) \delta(\mathrm{ppm}) 4.68(\mathrm{sept}, 1 \mathrm{H}, J=4.8 \mathrm{~Hz}), 4.39(\mathrm{q}, 1 \mathrm{H}$, $J=7.2 \mathrm{~Hz}), 3.94(\mathrm{dd}, 1 \mathrm{H}, J=10.8,2.8 \mathrm{~Hz}), 3.29(\mathrm{~d}, 1 \mathrm{H}, J=11.2 \mathrm{~Hz}), 2.01(\mathrm{~s}, 3 \mathrm{H}), 1.07(\mathrm{~d}, 3 \mathrm{H}$, $J=7.2 \mathrm{~Hz}), 0.98(\mathrm{~d}, 3 \mathrm{H}, J=6.8 \mathrm{~Hz}), 0.83(\mathrm{~s}, 3 \mathrm{H}), 0.75(\mathrm{~s}, 3 \mathrm{H}) .{ }^{13} \mathrm{C} \mathrm{NMR}\left(100 \mathrm{MHz}, \mathrm{CDCl}_{3}\right)$ 
$\delta$ (ppm) 170.9, 109.9, 81.1, 77.4, 73.8, 65.3, 62.1, 56.4, 54.3, 44.8, 42.3, 40.7, 40.2, 36.9, 35.7, 35.2, 34.2, 32.3, 31.9, 28.7, 27.6, 27.2, 26.1, 25.9, 21.6, 21.1, 16.7, 16.2, 14.5, 12.4. HRMS-ESI $(\mathrm{m} / z)$ calcd for $\mathrm{C}_{29} \mathrm{H}_{46} \mathrm{O}_{4}: 481.3288[\mathrm{M}+\mathrm{Na}]^{+}$found: $481.3288[\mathrm{M}+\mathrm{Na}]^{+}$. FTIR-ATR (neat) $v\left[\mathrm{~cm}^{-1}\right] 2945,2846,1724,1446,1379,1240,1027,987,919,854,611 . \mathrm{R}_{\mathrm{f}} 0.50(10 \%$ EtOAc/hexanes) [CAM]. Mp $172-174{ }^{\circ} \mathrm{C}$ [lit. $\left.176-178{ }^{\circ} \mathrm{C}\right][46]$.

${ }^{*} N O T E$ : Only the major $\mathrm{C}_{25}$ isomer was characterized. The ratio of OAc-2 to 25-epiOAc-2 was identical to the ratio of 2 to 25-epi-2.

16: ${ }^{1} \mathrm{H}$ NMR $\left(400 \mathrm{MHz}, \mathrm{CDCl}_{3}\right) \delta(\mathrm{ppm}) 4.74-4.63(\mathrm{~m}, 2 \mathrm{H}), 3.21(\mathrm{dd}, 1 \mathrm{H}, J=12.0$, $5.6 \mathrm{~Hz}), 3.07(\mathrm{dd}, 1 \mathrm{H}, J=12.0,7.2 \mathrm{~Hz}), 2.44(\mathrm{~d}, 1 \mathrm{H}, J=10.0 \mathrm{~Hz}), 2.17-2.07(\mathrm{~m}, 3 \mathrm{H}), 2.00$ $(\mathrm{s}, 3 \mathrm{H}), 0.95(\mathrm{~d}, 3 \mathrm{H}, \mathrm{J}=6.8 \mathrm{~Hz}), 0.82(\mathrm{~s}, 3 \mathrm{H}), 0.65(\mathrm{~s}, 3 \mathrm{H}) .{ }^{13} \mathrm{C} \mathrm{NMR}\left(100 \mathrm{MHz}, \mathrm{CDCl}_{3}\right) \delta$ (ppm) 170.8, 151.3, 104.2, 84.5, 73.8, 64.4, 57.8, 54.8, 54.3, 44.7, 43.7, 39.8, 36.9, 35.7, 34.9, 34.1, 33.2, 32.4, 31.5, 28.6, 27.6, 23.3, 21.6, 21.3, 17.6, 14.3, 12.4, 11.8. HRMS-ESI $(\mathrm{m} / \mathrm{z})$ calcd for $\mathrm{C}_{27} \mathrm{H}_{42} \mathrm{~N}_{3} \mathrm{O}: 484.3534[\mathrm{M}+\mathrm{H}]^{+}$found: $484.3528[\mathrm{M}+\mathrm{H}]^{+}$. FTIR-ATR (neat) $v\left[\mathrm{~cm}^{-1}\right]$ 2916, $2844,2096,1735,1689,1448,1367,1236,1027,663 . R_{\mathrm{f}} 0.52$ (10\% EtOAc/hexanes) [CAM]. $\operatorname{Mp} 58-60{ }^{\circ} \mathrm{C}$

\subsubsection{Synthesis of Tomatidine (1)}

A 1 L round-bottom flask was charged with 16 (9.91 g, 20.5 mmol, 1.0 eq. $)$, sodium iodide $(6.76 \mathrm{~g}, 45.1 \mathrm{mmol}, 2.2 \mathrm{eq}$.), and a stir bar, followed by addition of ACN (240 mL). This mixture was stirred until all the solids were dissolved (30 $\mathrm{min})$ before a solution of trimethylsilyl chloride (5.98 mL, $47.1 \mathrm{mmol}, 2.3$ eq.) in ACN (40 mL) was added dropwise. The mixture was stirred at room temperature and quickly turned purple. After stirring for $1 \mathrm{~h}$ at room temperature, sat. $\mathrm{Na}_{2} \mathrm{~S}_{2} \mathrm{O}_{3 \text { (aq.) }}(60 \mathrm{~mL})$ was added, and the $\mathrm{pH}$ was adjusted to 7 using $2 \mathrm{M} \mathrm{NaOH}$ (ca. $40 \mathrm{~mL}$ ). The volatiles were then removed in vacuo to give a yellow suspension, which was added to water $(100 \mathrm{~mL})$ and extracted with $\mathrm{CHCl}_{3}(4 \times 75 \mathrm{~mL})$. The organic layers were combined, washed with brine $(30 \mathrm{~mL})$, dried over $\mathrm{Na}_{2} \mathrm{SO}_{4}$, and concentrated in vacuo. The obtained solid was then transferred to a $1 \mathrm{~L}$ round-bottom flask and dissolved in a 3:1 MeOH/DCM mixture (350 mL). Subsequently, a $3 \mathrm{M} \mathrm{NaOH}$ solution (34.1 mL, $102 \mathrm{mmol}, 5.0$ eq.) was added, and the reaction was stirred at room temperature. After $2 \mathrm{~h}, 1 \mathrm{M} \mathrm{HCl}$ (ca. $70 \mathrm{~mL}$ ) was used to adjust the mixture to $\mathrm{pH}$ 6. The volatiles were removed in vacuo, and the mixture was suspended in water $(150 \mathrm{~mL})$ and extracted with $\mathrm{CHCl}_{3}(4 \times 75 \mathrm{~mL})$. The organic layers were combined, washed with brine $(30 \mathrm{~mL})$, dried over $\mathrm{Na}_{2} \mathrm{SO}_{4}$, and concentrated in vacuo. The crude material was passed through a silica pad $(6 \mathrm{~cm} \times 14 \mathrm{~cm})$ using 60:39:1 EtOAc/hexanes:Et ${ }_{3} \mathrm{~N}(1.5 \mathrm{~L})$ as an eluent. The filtrate was concentrated in vacuo to yield an amorphous yellow solid $(6.95 \mathrm{~g}, 82 \%)$ in a 5.9:1 ratio of 1 to 17. Product 1 was crystallized selectively by dissolving the crude solid in a 3:1 $\mathrm{MeOH} / \mathrm{DCM}$ mixture $(80 \mathrm{~mL})$ in a crystallizing dish, which was placed in a hermetically closed larger container containing $\mathrm{MeOH}$ (See Supplementary Materials). After $48 \mathrm{~h}$, the supernatant was removed from the crystallizing dish, and the crystals were collected and dried. This process was repeated a second time, and the products were combined to yield 1 (5.17 g, 61\%, two steps) as colorless crystals in a 9:1 ratio of 1 to 17 (purity 90\%).

${ }^{1} \mathrm{H} \mathrm{NMR}\left(400 \mathrm{MHz}, \mathrm{CDCl}_{3}\right) \delta(\mathrm{ppm}) 4.10(\mathrm{q}, 1 \mathrm{H}, J=8.4 \mathrm{~Hz}), 3.55$ (sept, $\left.1 \mathrm{H}, J=4.8 \mathrm{~Hz}\right)$, 2.75-2.69 (m, 2H), 2.00-1.94 (m, 1H), $0.94(\mathrm{~d}, 3 \mathrm{H}, J=7.2 \mathrm{~Hz}), 0.83(\mathrm{~d}, 3 \mathrm{H}, J=6.4 \mathrm{~Hz}), 0.80$ (s, $3 \mathrm{H}), 0.79$ (s, 3H). ${ }^{13} \mathrm{C} \mathrm{NMR}\left(100 \mathrm{MHz}, \mathrm{CDCl}_{3}\right) \delta(\mathrm{ppm}) 99.1,78.6,71.3,62.1,55.9,54.5,50.3$, $44.9,43.1,40.9,40.3,38.3,37.1,35.7,35.2,32.8,32.4,31.6,31.1,28.7,28.6,26.7,21.2,19.5,17.1$, $15.9,12.5$. HRMS-ESI $(\mathrm{m} / \mathrm{z})$ calcd for $\mathrm{C}_{27} \mathrm{H}_{45} \mathrm{NO}_{2}: 416.3523[\mathrm{M}+\mathrm{H}]^{+}$found: $416.3517[\mathrm{M}+\mathrm{H}]^{+}$. FTIR-ATR (neat) $v\left[\mathrm{~cm}^{-1}\right]$ 3315, 2914, 2852, 1444, 1382, 1137, 1049, 975, 900, 869, 786, 655. $\mathrm{R}_{\mathrm{f}} 0.45\left(60 \%\right.$ EtOAc/hexanes, $\left.1 \% \mathrm{Et}_{3} \mathrm{~N}\right)$ [CAM]. Mp 208-210 ${ }^{\circ} \mathrm{C}$ [lit. 206-208 $\left.{ }^{\circ} \mathrm{C}\right][47]$. The spectroscopic data were in agreement with previously reported data $[15,48]$.

\section{Conclusions}

In summary, we developed and optimized a 15-step synthesis (11 steps LLS) of the potent alkaloid tomatidine in $15.2 \%$ overall yield starting from dinorcholanic lactone 5 . This methodology enabled us to produce 5.2 grams of tomatidine in a single pass using 
fine-tuned reaction sequences that require no flash chromatography purifications. We hope that this methodology can bridge the gap between what is synthetically feasible in the lab and what is industry-viable and that it can pave the way for easier access to this potent and promising biologically active natural product.

Supplementary Materials: The following are available online, Table S1: Crystal Data and Structure Refinement for 1, Figures S1-S22: ${ }^{1} \mathrm{H}$ and ${ }^{13} \mathrm{C}$ NMR spectra of compounds 1, 2, OAc-2, 7, 8, 9a, 11-13, 15 and 16, Figure S23: Vapor Diffusion Apparatus for the Crystallization of $\mathbf{1 .}$

Author Contributions: Conceptualization, methodology, investigation, writing-original draft preparation and editing by C.N.; Supervision, funding acquisition, review and editing by P-L.B. All authors have read and agreed to the published version of the manuscript.

Funding: This research was funded by FRQNT-funded PROTEO network, grant number FT109664 and privately funded. The publication charges for this article have been funded by the University of Sherbrooke.

Institutional Review Board Statement: Not applicable.

Informed Consent Statement: Not applicable.

Data Availability Statement: Copies of NMR spectra for all synthesized compounds and abridged crystallographic data of $\mathbf{1}$ are available in the Supplementary Materials. Extended crystallographic data of $\mathbf{1}$ is available at the Cambridge Crystallographic Data Centre (ccdc.cam.ac.uk - deposition number 2090407).

Acknowledgments: Financial support from PROTEO is gratefully acknowledged. PLB is a member of the FRQNT-funded PROTEO Network as well as the FRQS-funded Quebec Network for Drug Discovery.

Conflicts of Interest: The authors declare no conflict of interest.

Dedication: This work is dedicated to the loving memory of the late Pr. Éric Marsault, an outstanding researcher, professional investigator, mentor, and friend who passed away too early.

Sample Availability: No samples are available from the authors.

\section{References and Note}

1. Kaunda, J.S.; Zhang, Y.-J. The Genus Solanum: An Ethnopharmacological, Phytochemical and Biological Properties Review. Nat. Prod. Bioprospect. 2019, 9, 77-137. [CrossRef] [PubMed]

2. Heretsch, P.; Giannis, A. The Vetratrum and Solanum Alkaloids. Alkaloids Chem Biol. 2015, 74, $201-232$.

3. Dyle, M.C.; Ebert, S.M.; Cook, D.P.; Kunkel, S.D.; Fox, D.K.; Bongers, K.S.; Bullard, S.A.; Dierdorff, J.M.; Adams, C.M. Systemsbased Discovery of Tomatidine as a Natural Small Molecule Inhibitor of Skeletal Muscle Atrophy. J. Biol. Chem. 2014, 289, 14913-14924. [CrossRef]

4. Koduru, S.; Jimoh, F.O.; Grierson, D.S.; Afolayan, A.J. Antioxidant Activity of Two Steroid Alkaloids Extracted from Solanum aculeastrum. J. Pharm. Toxicol. 2007, 2, 160-167. [CrossRef]

5. Chiu, F.-L.; Lin, J.-K. Tomatidine inhibits iNOS and COX-2 through suppression of NF- $\mathrm{B}$ and JNK pathways in LPS-stimulated mouse macrophages. FEBS Lett. 2008, 582, 2407-2412. [CrossRef] [PubMed]

6. Troost, B.; Mulder, L.M.; Diosa-Toro, M.; van de Pol, D.; Rodenhuis-Zybert, I.A.; Smit, J.M. Tomatidine, a natural steroidal alkaloid shows antiviral activity towards chikungunya virus in vitro. Sci. Rep. 2020, 10, 6364-6375. [CrossRef] [PubMed]

7. Diosa-Toro, M.; Troost, B.; van de Pol, D.; Heberle, A.M.; Urcuqui-Inchima, S.; Thedieck, K.; Smit, J.M. Tomatidine, a Novel Antiviral Compounds Towards Dengue Virus. Antiviral Res. 2019, 161, 90-99. [CrossRef] [PubMed]

8. Yan, K.-H.; Lee, L.-M.; Yan, S.-H.; Huang, H.-C.; Li, C.-C.; Lin, H.-T.; Chen, P.-S. Tomatidine Inhibits Invasion of Human Lung Adenocarcinoma Cells A549 by Reducing Matrix Metalloproteinases Expression. Chem.-Biol. Interact. 2013, 203 , 580-587. [CrossRef] [PubMed]

9. Guay, I.; Boulanger, S.; Isabelle, C.; Brouillette, E.; Chagnon, F.; Bouarab, K.; Marsault, E.; Malouin, F. Tomatidine and Analog FC04-100 Possess Bactericidal Activities Against Listeria, acillus and Staphylococcus spp. BMC Pharmacol. Toxicol. 2018, 19, 7-18. [CrossRef] [PubMed]

10. Mitchell, G.; Gattuso, M.; Grondin, G.; Marsault, É.; Bouarab, K.; Malouin, F. Tomatidine Inhibits Replication of Staphylococcus aureus Small-Colony Variants in Cystic Fibrosis Airway Epithelial Cells. Antimicrob. Agents Chemother. 2011, 55, 1937-1945. [CrossRef] 
11. Boulet, M.L.; Isabelle, C.; Guay, I.; Brouillette, E.; Langlois, J.-P.; Jacques, P.-E.; Rodrigue, S.; Brzezinski, R.; Beauregard, P.B.; Bouarab, K.; et al. Tomatidine Is a Lead Molecule That Targets Staphylococcus aureus ATP Synthase Subunic C. Antimicrob. Agents Chemother. 2018, 62, e02197-17.

12. Chagnon, F.; Guay, I.; Bonin, M.-A.; Mitchell, G.; Bouarab, K.; Malouin, F.; Marsault, E. Unraveling the Structure-Activity Relationship of Tomatidine, A Steroid Alkaloid With Unique Antibiotic Properties Against Persistent Forms of Staphylococcus aureus. Eur. J. Med. Chem. 2014, 80, 605-620. [CrossRef]

13. Mitchell, G.; Lafrance, M.; Boulanger, S.; Seguin, D.L.; Guay, I.; Gattuso, M.; Marsault, E.; Bouarab, K.; Malouin, F. Tomatidine Acts in Synergy with Aminoglycoside Antibiotics against Multiresistant Staphylococcus aureus and Prevents Virulence Gene Expression. J. Antimicrob. Chemother. 2012, 67, 559-568. [CrossRef]

14. Kuttruff, C.A.; Eastgate, M.D.; Baran, P.S. Natural Product Synthesis in The Age of Scalability. Nat. Prod. Rep. 2014, 31, 419-432. [CrossRef]

15. Normandin, C.; Malouin, F.; Marsault, E. Gram-Scale Synthesis of Tomatidine, a Steroid Alkaloid with Antibiotic Properties Against Persistent Forms of Staphylococcus aureus. Eur. J. Org. Chem. 2020, 2693-2698. [CrossRef]

16. Wang, Y.; Huang, G.; Shi, Y.; Tian, W.-S.; Zhuang, C.; Chen, F.-E. Asymmetric Synthesis of (-)-Solanidine and (-)-Tomatidenol. Org. Biomol. Chem. 2020, 18, 3169-3176. [CrossRef] [PubMed]

17. Gaich, T.; Baran, P. Aiming for the Ideal Synthesis. J. Org. Chem. 2010, 75, 4657-4673. [CrossRef] [PubMed]

18. Budarin, V.L.; Shuttleworth, P.S.; Clark, J.H.; Luque, R. Industrial Application of C-C Coupling Reactions. Curr. Org. Synth. 2011, 7, 614-627. [CrossRef]

19. Potuzak, J.S.; Tan, D.S. Synthesis of C1-Alkyl and Acylglycals from Glycals Using a B-alkyl Suzuki-Miyaura Cross Coupling Approach. Tetrahedron Lett. 2004, 45, 1797-1801. [CrossRef]

20. Wang, S.-S.; Shi, Y.; Tian, W.-S. Highly Efficient and Scalable Synthesis of Clionamide D. Org. Lett. 2014, 16, 2177-2179. [CrossRef]

21. Shah, H.J.; Lele, S.S. Extraction of Diosgenin, a Bioactive Compound from Natural Source Dioscorea alata Var purpurae. J. Anal. Bioanal. Tech. 2012, 3, 141-143. [CrossRef]

22. Rafaniello, A.A.; Rizzacasa, M.A. Total Synthesis of (+)-Trachyspic Acid 19-n-Butyl Ester. Org. Lett. 2020, 22, 1972-1975. [CrossRef] [PubMed]

23. Tsushima, K.; Araki, K.; Murai, A. Conversion of Lactones into Substituted Cyclic Ethers. Chem. Lett. 1989, 18, 1313-1316. [CrossRef]

24. Boeckman, R.K.; Bruza, K.J. Cyclic Vinyl Ether Carbanions I: Synthetic Equivalents of $\beta$-acylvinyl and Substituted Acyl Anions. Tetrahedron Lett. 1977, 18, 4187-4190. [CrossRef]

25. Boeckman, R.K.; Bruza, K.J. Cyclic Vinyl Ether Carbanions-II: Preparation and Applications to The Synthesis of Carbonyl Compounds. Tetrahedron 1981, 37, 3997-4006. [CrossRef]

26. Torisawa, Y.; Shibasaki, M.; and Ikegami, S. Novel Reactivities on tert-Butyldimethylsilyl and tert-Butyldiphenylsilyl Ethers; Application to the Synthesis of 11-epi-PGF 2 a. Chem. Pharm. Bull. 1983, 31, 2607-2615. [CrossRef]

27. Franke, F.; Guthrie, R.D. 6,6'-Di-O-t-Butyldimethylsilylsucrose: Studies on the Rearrangements Accompanying Deblocking of Such Silyl Ethers. Aust. J. Chem. 1978, 31, 1285-1290. [CrossRef]

28. Shi, Y.; Xiao, Q.; Lan, Q.; Wang, D.-H.; Jia, L.-Q.; Tang, X.-H.; Zhou, T.; Li, M.; Tian, W.-S. A Synthesis of Cephalostatin 1. Tetrahedron 2018, 75, 1722-1738. [CrossRef]

29. Zenk, P.C.; Wiley, R.A. A General Synthesis for 4-Alkyl-2,3-dihydrofurans. Synthesis 1984, 8, 695-697. [CrossRef]

30. Garnsey, M.R.; Slutskyy, Y.; Jamison, C.R.; Zhao, P.; Lee, J.; Rhee, Y.H.; Overman, L.E. Short Enantioselective Total Syntheses of Cheloviolenes A and B and Dendrillolide C via Convergent Fragment Coupling Using a Tertiary Carbon Radical. J. Org. Chem. 2017, 83, 6958-6976. [CrossRef]

31. Friesen, R.W.; Loo, R.W. Preparation of C-aryl Glucals Via the Palladium-Catalyzed Coupling of Metalated Aromatics With 1-iodo-3,4,6-tri-O-(triisopropylsilyl)-D-glucal. J. Org. Chem. 1991, 56, 4821-4823. [CrossRef]

32. Paquette, L.A.; Lanter, J.C.; Johnston, J.N. Single Stereodifferentiation Associated with Carbon Atom Insertion during the Oxonium Ion-Initiated Pinacol Rearrangement of Dihydrofuranyl and Dihydropyranyl Carbinols. J. Org. Chem. 1997, 62, 1702-1712. [CrossRef]

33. Genicot, C.; Ley, S.V. Dispiroketals in Synthesis (Part 15): Simultaneous Protection and Enantioselective Desymmetrisation of Glycerol by Reaction with a C2-Symmetric Dimethyl bis-Dihydropyran. Synthesis 1994, 12, 1275-1277. [CrossRef]

34. Denmark, S.E.; Kobayashi, T.; Regens, C.S. Total Synthesis of (+)-Papulacandin D. Tetrahedron 2010, 66, 4745-4759. [CrossRef] [PubMed]

35. Ley, S.V.; Tackett, M.N.; Maddess, M.L.; Anderson, J.C.; Brennan, P.E.; Cappi, M.W.; Heer, J.P.; Helgen, C.; Kori, M.; Kouklovsky, C.; et al. Total Synthesis of Rapamycin. Chem. Eur. J. 2009, 15, 2874-2914. [CrossRef]

36. Luzzio, F.A.; Fitch, R.W.; Moore, W.J.; Mudd, K.J. A Facile Oxidation of Alcohols Using Pyridinium Chlorochromate/Silica Gel. J. Chem. Educ. 1999, 76, 974-975. [CrossRef]

37. Smith, A.B.; Lin, Q.; Doughty, V.A.; Zhuang, L.; McBriar, M.D.; Kerns, J.K.; Boldi, A.M.; Murase, N.; Moser, W.H.; Brook, C.S.; et al. Spongipyran synthetic studies. Total Synthesis of (+)-Spongistatin 2. Tetrahedron 2009, 65, 6470-6488. [CrossRef]

38. Tobari, A.; Teshima, M.; Koyanagi, J.; Kawase, M.; Miyamae, H.; Yoza, K.; Takasaki, A.; Nagamura, A.; Saito, S. Spirostanols Obtained by Cyclization of Pseudosaponin Derivatives and Comparison of Anti-Platelet Agglutination Activities of Spirostanol Glycosides. Eur. J. Med. Chem. 2000, 35, 511-527. [CrossRef] 
39. Kemsley, J.N. Learning from UCLA. Chem. Eng. News 2009, 87, 29-34. [CrossRef]

40. Wu, J.-J.; Shi, Y.; Tian, W.-S. Facile synthesis of solasodine based on a mild halogenation-ring opening reaction of spiroketals in steroidal sapogenins. Tetrahedron Lett. 2015, 56, 1215-1217. [CrossRef]

41. Li, Y.; Zhang, Y.; Guo, T.; Guan, H.; Hao, Y.; Yu, B. Synthesis of the Cytotoxic Gitogenin 3 $\beta-O-[2-O-(\alpha-1-R h a m n o p y r a n o s y l)-\beta-d-$ galactopyranoside] and its Congeners. Synthesis 2006, 5, 775-782. [CrossRef]

42. Watson, S.C.; Eastham, J.F. Colored Indicators for Simple Direct Titration of Magnesium and Lithium Reagents. J. Organomet. Chem. 1967, 9, 165-168. [CrossRef]

43. Molander, G.A.; Etter, J.B.; Zinka, P.W. Stereocontrolled Cyclization Reactions Mediated by Samarium Diiodide. J. Am. Chem. Soc. 1987, 109, 453-463. [CrossRef]

44. The conversion was calculated by integration of the $\mathrm{H}_{22}$ shift at $\delta=6.00 \mathrm{ppm}$.

45. Callow, R.K.; James, V.H.T. Epimerisation at C(25) of Steroid Sapogenins: Sarsasapogenin, Neotigogenin, and Sisalagenin. J. Chem. Soc. 1955, 1671-1674. [CrossRef]

46. Tschesche, R.; Wulff, G.; Balle, G. Über saponine der spirostanolreihe-VIII: Über das gemeinsame vorkommen von $25 \alpha-$ und $25 \beta$-sapogeninen in den saponinen von digitalis purpurea L. und digitalis lanata ehrh. Tetrahedron 1962, 18, 959-967. [CrossRef]

47. Sato, Y.; Latham Jr, H.G. Chemistry of Dihydrotomatidines. J. Am. Chem. Soc. 1956, 78, 3146-3150. [CrossRef]

48. Matsushita, S.; Yanai, Y.; Fusyuku, A.; Fujiwara, Y.; Ikeda, T.; Ono, M.; Han, C.; Ojika, M.; Nohara, T. Efficient Conversion of Tomatidine into Neuritogenic Pregnane Derivative. Chem. Pharm. Bull. 2007, 55, 1077-1078. [CrossRef] 